\title{
FELLOW JOURNEYERS WALT WHITMAN AND JESSE TALBOT: PAINTING, POETRY, AND PUFFERY IN 1850s NEW YORK
}

\section{$\rightarrow \operatorname{cosectax}$ \\ JESSICA SKWIRE ROUTHIER}

WaLt Whitman SCHOLARs have long known of the existence of Jesse Talbot: he is the Brooklyn-based artist-friend of Whitman's whose name appears inside the eponymous Talbot Wilson notebook, in which Whitman first jotted down the ideas that would one day become Leaves of Grass. ${ }^{1}$ Whitman wrote about and promoted Talbot's paintings in several newspaper and journal articles in the 1850s, and he also owned one: Christian at the Cross, a scene from The Pilgrim's Progress, recently rediscovered in a private American collection (figure 1). ${ }^{2}$

Several Whitman scholars, including Ruth Bohan and, recently, Wendy Katz ${ }^{3}$ have looked into Talbot as one of Whitman's circle of friends and as a subject for his art journalism-but until now little has been written about Talbot's own artwork and personal history. This article will trace Talbot's professional development in tandem with Whitman's, exploring how both artists, in different media, used related imagery and punning motifs, as well as the theme of pilgrimage, to articulate and promote a shared vision for American arts and culture. It draws on new primary evidence about Talbot and Whitman's promotion of him to demonstrate how Whitman's critical response to Talbot's work shaped both men's careers - for better and for worse.

I first encountered Talbot not as a Whitman scholar but as an art curator, back in 2008, in my first days as director of the Saco Museum, a small museum of art and history just south of Portland, Maine. ${ }^{4}$ While familiarizing myself with the paintings collection, I saw on the racks what was clearly an exceptional mid-nineteenth-century landscape painting, even though it was darkened with age (figure 2). A small plaque on the frame read "Tropical Scenery-Early Morning - Talbot's Masterpiece,"5 and my first thought was, "Talbot who?" Although I'd been researching and writing about mid-nineteenth-century American landscape painting for more than a dozen years by then, I had never heard of him. 


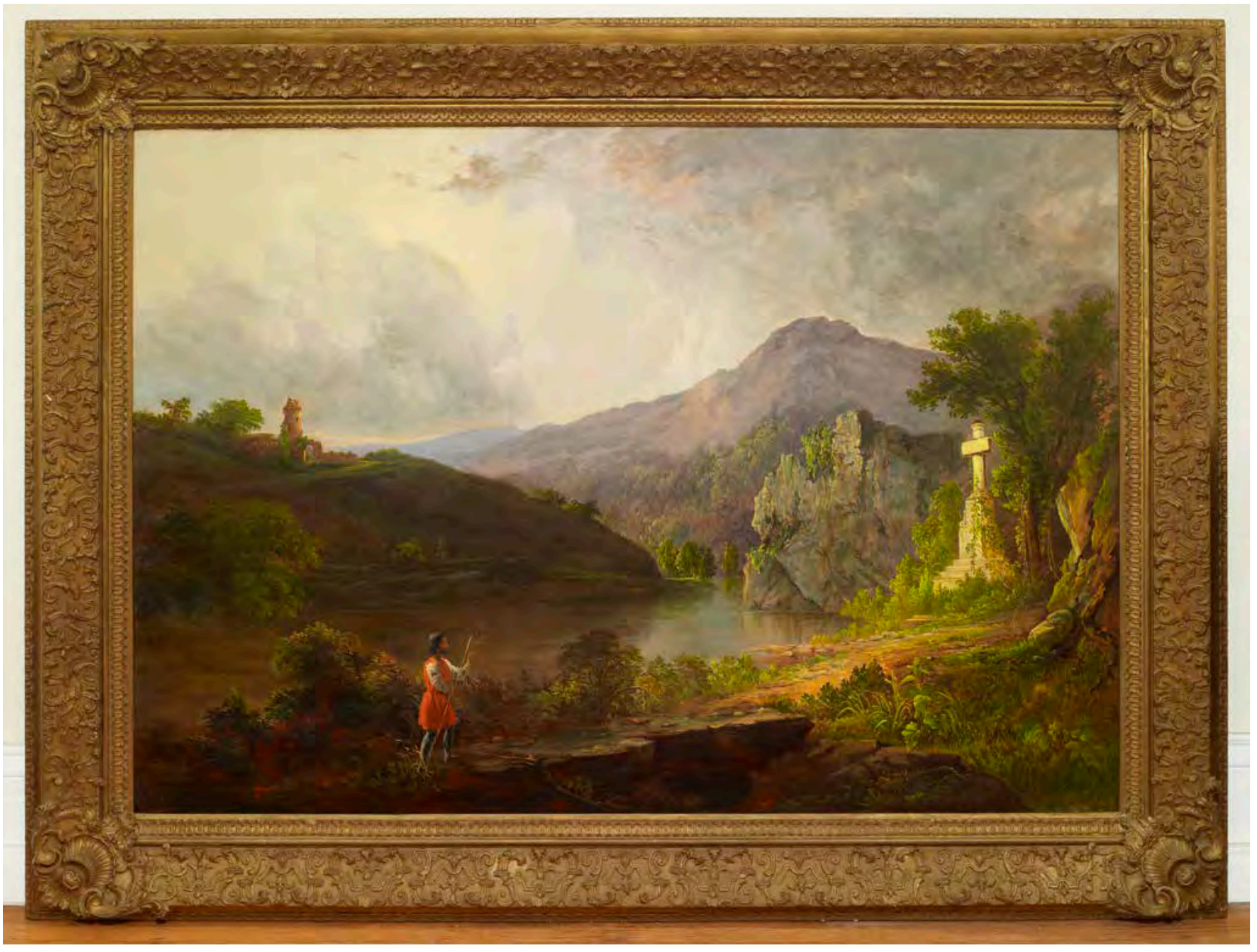

Figure 1: Jesse Talbot (American, 1805-1879), Christian at the Cross, 1847, oil on canvas, 29 x 57 in. Private collection. Photo by Bif Hendrix.

A look into the object files gave me the artist's first name and the information that he was one of a group of artists known to have painted scenes from The Pilgrim's Progress in the mid-1800s. In this regard he was at least marginally connected to another important object in the Saco Museum's collection: an original, eight-foot-high, eight hundred-foot-long moving panorama based on The Pilgrim's Progress that was made by artists associated with New York's National Academy of Design between 1850 and 1851 (figure 3). ${ }^{6}$ As I prepared for a major exhibition of the Moving Panorama of Pilgrim's Progress in 2012, including a book and a full-scale performance replica, ${ }^{7}$ I learned that several major New York-based artists also exhibited work based on The Pilgrim's Progress in the years preceding the Panorama's debut, and nearly all of them ended up contributing designs to it and being part of its creation-but not Talbot. Why? And why didn't anybody know anything about him? And where were his Pilgrim's Progress paintings today? 


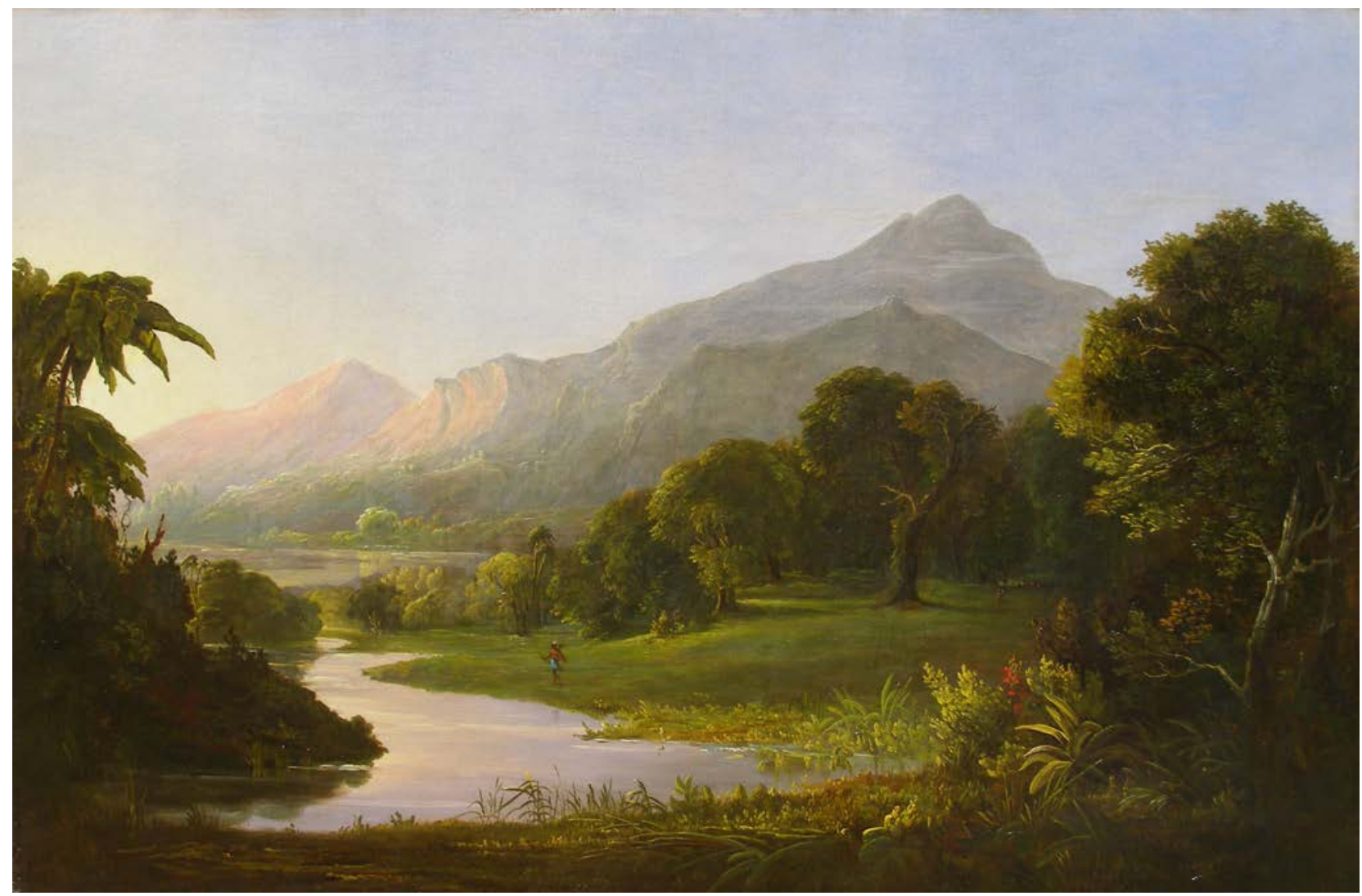

Figure 2: Jesse Talbot, Tropical Scenery-Early Morning, 1850, oil on canvas. Collections of the Dyer Library and Saco Museum, Saco, Maine. Photo by Martha Cox.

A partial answer to the latter question, at least, came relatively soon, when I was contacted by a private collector who had seen Tropical Scenery on the museum's website and wanted to learn more about Talbot-because he owned a painting by him titled Christian at the Cross, a scene from The Pilgrim's Progress. It seemed like a sign from God-and yet there was still so much we didn't know. The art-historical literature on Talbot is extremely scant; David Dearinger's definitive book on the artists of the National Academy just guesses at his birthdate and states that "nothing is known about him before 1838," which is when he first appears in the Academy's exhibition records. ${ }^{8}$ Dearinger also does not mention Talbot's connection to Whitman, and this is partly why it would be some time before either the collector or I would understand that this Christian at the Cross painting was the same composition, if not the same actual canvas, as the one once owned by Whitman.

Part of the reason that Talbot's personal history has been something of a 


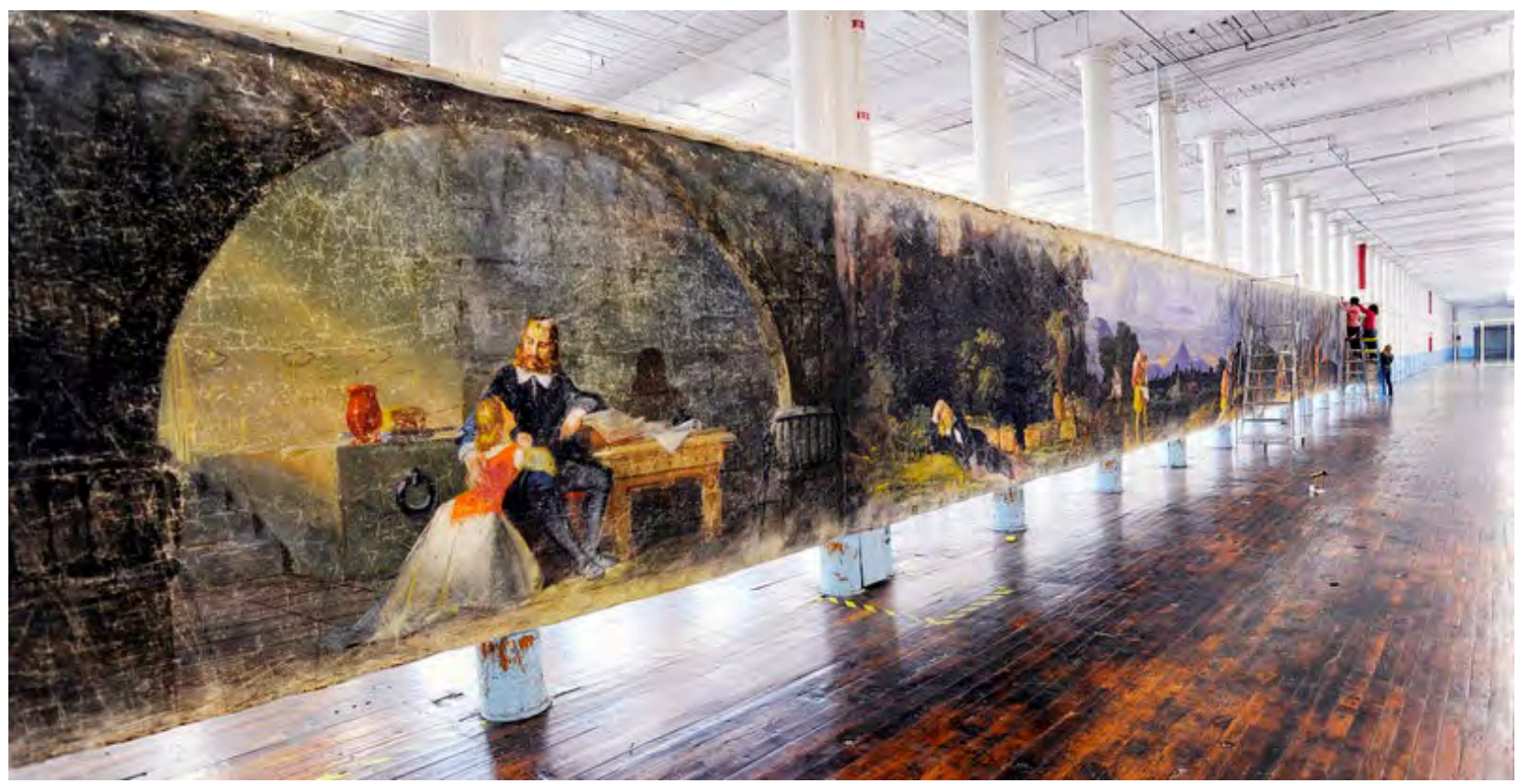

Figure 3: Jacob Dallas, Joseph Kyle, and Edward Harrison May, The Moving Panorama of Pilgrim's Progress, 1851, distemper on muslin, 8 x 800 feet. Collections of the Dyer Library and Saco Museum, Saco, Maine, Gift of the heirs of Luther Bryant, 1896. Photographed at Pepperell Mill Campus, Biddeford, Maine, June 18, 2012, by Shawn Patrick Ouellette, courtesy Portland Press Herald/Maine Sunday Telegram.

mystery up until now is that, while he was demonstrably prolific with paintings, he was less so with words. If diaries or other substantial archives exist, they have not yet been found; ${ }^{9}$ he also did not apparently give lectures or write newspaper columns in the way that so many of his colleagues did. Dearinger's speculative birth date of 1806 to 1807 seems to have been based on the mathematical knowledge that he was seventy-three years old when he died in $1879 .{ }^{10} \mathrm{But}$ Talbot died in January from injuries sustained a few days earlier by slipping on the ice, which means that he turned seventy-three the previous year, 1878, and was born in 1805. Indeed, that small adjustment has opened the door to Talbot's full biography. I detail it here for the first time, before going on to discuss his relationship with Whitman and some compelling parallels between their work.

Jesse Talbot was born April 1, 1805, in Dighton, Massachusetts, near the Rhode Island border. He was fondly remembered in an 1883 history of Bristol County as a "worthy representative" of the town in the world of art. ${ }^{11}$ The author 
of this local history identifies him as the son of Josiah and Lydia Talbot and writes that he was raised "on a farm in the northwest part of the town" before outlining a brief early biography: "Before he had reached the age of manhood he went to Dedham, in this State, and was employed as a clerk in the store of Dr. Wheaton. From Dedham he removed to New York City, where he was appointed secretary of the American Tract Society and married the daughter of a clergyman." Local birth records confirm that Jesse Talbot was, indeed, the eighth and last child born to Josiah Talbot and one Lydia Wheaton, who in turn was the eleventh of thirteen children. ${ }^{12}$ Lydia's youngest brother, the baby of the family, was Jesse Wheaton, the future Dr. Wheaton ${ }^{13}$ - almost certainly the source of the name she gave her own youngest child.

Talbot must have been very young-"before the age of manhood," as his hometown biographer wrote-when he left home to work in his uncle's store in Dedham, Massachusetts, outside of Boston. ${ }^{14}$ Under his uncle's care, Talbot was exposed to a world of ideas. Wheaton was active in many local and national charitable causes, all of which were at the time inextricably linked with the rising Christian evangelical movement, including the American Tract Society, of which he was identified as a "life member" in 1823. ${ }^{15}$ This last affiliation apparently made a particular impression on the young Talbot, because by 1829 his employer was no longer his uncle but the American Tract Society, at its Nassau Street headquarters in New York. ${ }^{16}$

For the first ten years of his New York life-from 1829 until 1838-Talbot was not an artist at all, but rather a committed member of and worker for the city's religious reform community. ${ }^{17} \mathrm{He}$ also seems to have had some involvement in the anti-slavery movement-Christian evangelism and social justice reform generally went hand-in-hand in pre-Civil War America-although it seems likely that a later genealogist confused him with a different Jesse Talbot in describing him as "one of the original abolitionists." 18 Talbot's real vocation, at least at first, was spreading the gospel. He began by doing this in the most literal way: distributing tracts along the wharves of New York City.

Sometime before 1834 Talbot had risen to the position of "Assistant Secretary" in the American Tract Society ${ }^{19}$ - close to, if not exactly, what his Dighton biographer had described-and also became involved with the American Board of Commissioners for Foreign Missions (ABCFM), a national Christian missionary organization whose stated goal was to spread Christianity worldwide, including to America's Indigenous populations. ${ }^{20}$ The ABCFM was also known for its progressive politics, notably its outspoken resistance to the Indian Removal Act of 1830 . It was through this latter connection that he came 
in contact with the Reverend Richard Sluyter of Claverack, New York, whose daughter he married in the Dutch Reform church there, with Sluyter presiding, in $1836 .^{21}$

Also around this time, Talbot's name begins to appear in the annual reports of the New York Tract Society-an auxiliary of the American Tract Society-with a new title, "recording secretary," signaling that he was the individual responsible for preparing, and most likely authoring, those same reports. ${ }^{22}$ With that role in mind, the annual reports published under his tenure from 1835 to 1837 may be the only extensive words we have in Jesse Talbot's voice. If that is the case, they offer some tantalizing hints of his future interests as a landscape painter whose works would one day be held up by Walt Whitman as exemplars of the ideal practice of art, spirituality, and republican American values.

To begin with, there are many references to The Pilgrim's Progress, which is only to be expected during a time and place in which the book was second in popularity only to the Bible; it was also among the titles printed by the American Tract Society itself. ${ }^{23}$ Written by the English Reform preacher John Bunyan, The Pilgrim's Progress (1678) is an allegory that tells the story of the protagonist, Christian's, journey from his home in the City of Destruction, representing the world in its fallen state, to the Celestial City, representing salvation. Correspondingly, in Talbot's 1835 report, readers are warned of the day "when this and every city . . . 'shall be burned up" in an "awful conflagration"” and are exhorted to "flee from the wrath to come" - a direct quote from Bunyan - in order to one day "enter into the heavenly city individually." 24

Talbot's minutes also embrace and expand upon Bunyan's metaphor of landscape as the setting for Christian pilgrimage. The report for the tenth annual meeting exalts the society's primary mission of publishing and distributing evangelical tracts by saying that the enterprise "blooms like the tree on the banks of the river of life" - the Tree and the River of Life are both material presences in The Pilgrim's Progress - "which gives her monthly fruit, rich and nutritious, while its leaves are for the healing of the people" (emphasis original). ${ }^{25}$ The moment in The Pilgrim's Progress in which Christian is healed by applying the leaves of the Tree of Life to his wounds, after fighting the monster Apollyon, is not one of the best remembered or more commonly illustrated scenes from the book, but it is depicted in the Moving Panorama of Pilgrim's Progress, where it serves to demonstrate just how literally nineteenth-century readers would have perceived these words (figure 4).

Nineteen years later, Walt Whitman would similarly conflate natural leaves with the leaves of a book in the title for his magnum opus, Leaves of Grass. It was 


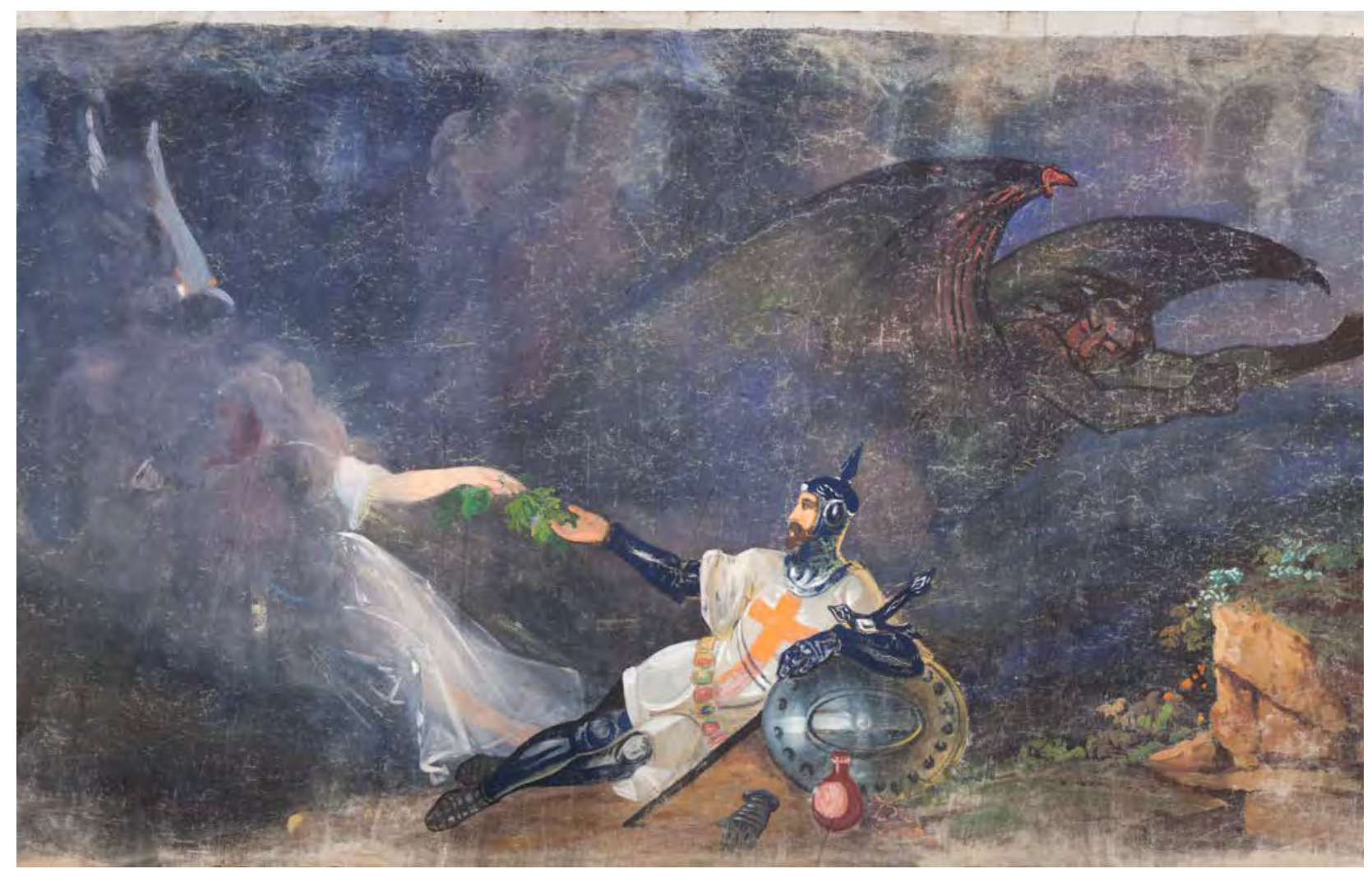

Figure 4: Christian Reposing after the Combat, design attributed to Joseph Kyle, from The Moving Panorama of Pilgrim's Progress. Photo by Matthew Hamilton, Williamstown Art Conservation Center.

a metaphor that retained relevance to him throughout his many revisions of that work. In the poem "Starting from Paumanok" that first appeared as "ProtoLeaf" in the $3^{\text {rd }}$ edition of Leaves (1860), Whitman writes about "applying these leaves to the new ones from the hour they unite with the old ones" (emphasis added), a phrase that is somewhat confounding without the supporting idea of the laying on of natural leaves for healing purposes, as a kind of wound dressing. ${ }^{26}$ Whitman kept these lines in the poem throughout the subsequent editions of Leaves of Grass, and it is intriguing to consider the implications of his sustained attraction to this metaphor throughout his life, in the years after his work as a nurse to the wounded of the Civil War and into the time when he was dependent upon caregivers himself. None of this, of course, is to suggest that Whitman was looking to Talbot, or even necessarily to Bunyan, for cues in crafting and refining the imagery for Leaves of Grass. Instead, we might read all of this as evidence of a fertile cultural field in which Talbot was an active 
participant and in which Whitman's ideas would one day take root as well.

Abruptly, in 1838, Talbot disappears from the annual reports of New-York Tract Society and instead makes his first appearance in the annual exhibition records of the National Academy of Design, where he exhibited two portraits and a landscape. ${ }^{27}$ The career change seems so sudden and irrevocable-Talbot never went back to professional missionary work-that it is tempting to believe that we are, once again, dealing with two different Jesse Talbots. How does a religious paper-pusher, a Massachusetts farm boy with no apparent background in the visual arts, vault himself directly into the galleries of the National Academy? Some likely answers are primarily speculative. It seems probable, although it is not yet confirmed, that he had been taking classes at the National Academy for some time before the 1838 exhibition and thus already had a relationship with the institution as a student. We also know that he had dabbled in artistic work while still affiliated with the Tract Society; his earliest known extant work is a portrait frontispiece for a biography printed by the society at Nassau street, in the heart of New York's publishing world. ${ }^{28}$ Another early coup that bridges Talbot's two careers - and one that better showed his skills and interests as an artist - was the engraved reproduction of his 1840 painting Rockland Lake in The Token and Atlantic Souvenir of 1842 (figure 5), a kind of lavish holiday gift book known for its illustrations and its early publication of authors like Nathaniel Hawthorne and Edgar Allan Poe. ${ }^{29}$

The painted version of Rockland Lake is currently unlocated, but the engraving from The Token remains. It is an astonishingly mature view for a novice artist, demonstrating a complete understanding and adoption of the

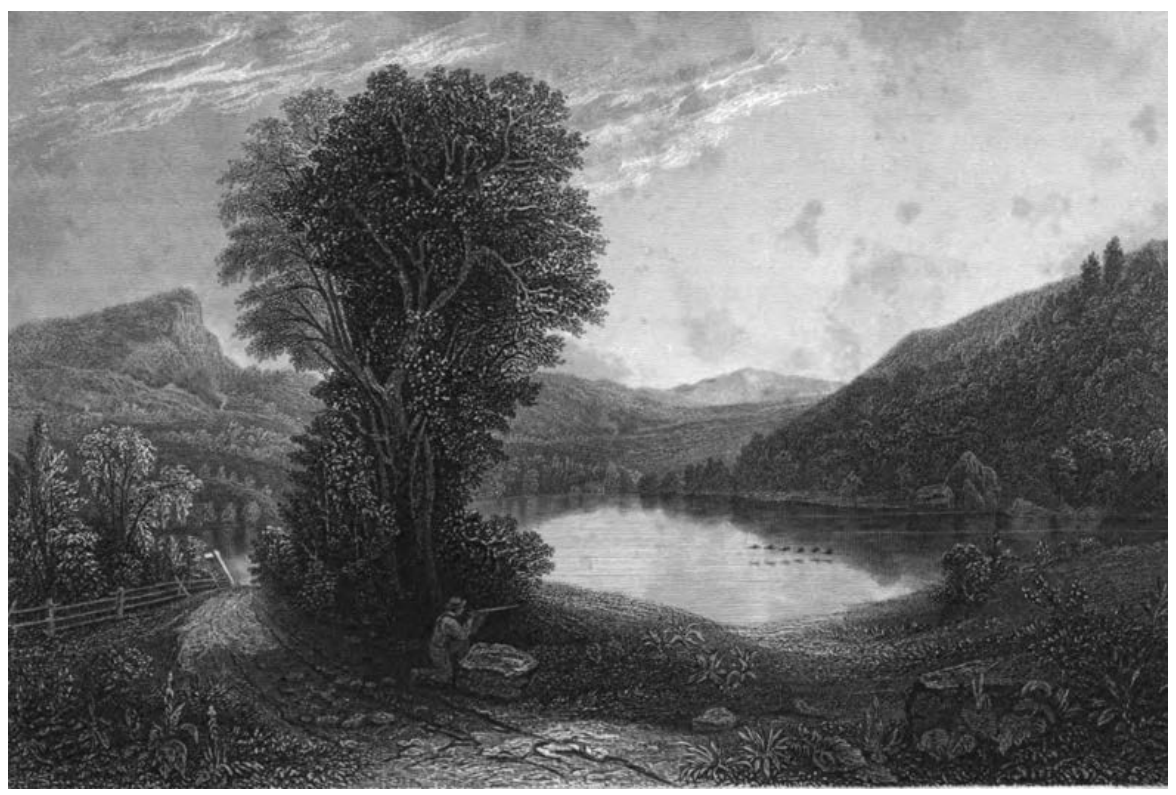

Figure 5: After Jesse

Talbot, Rockland Lake, in The Token and Atlantic Souvenir: An Offering for Christmas and the New Year (Boston: David H. Williams, 1842). 


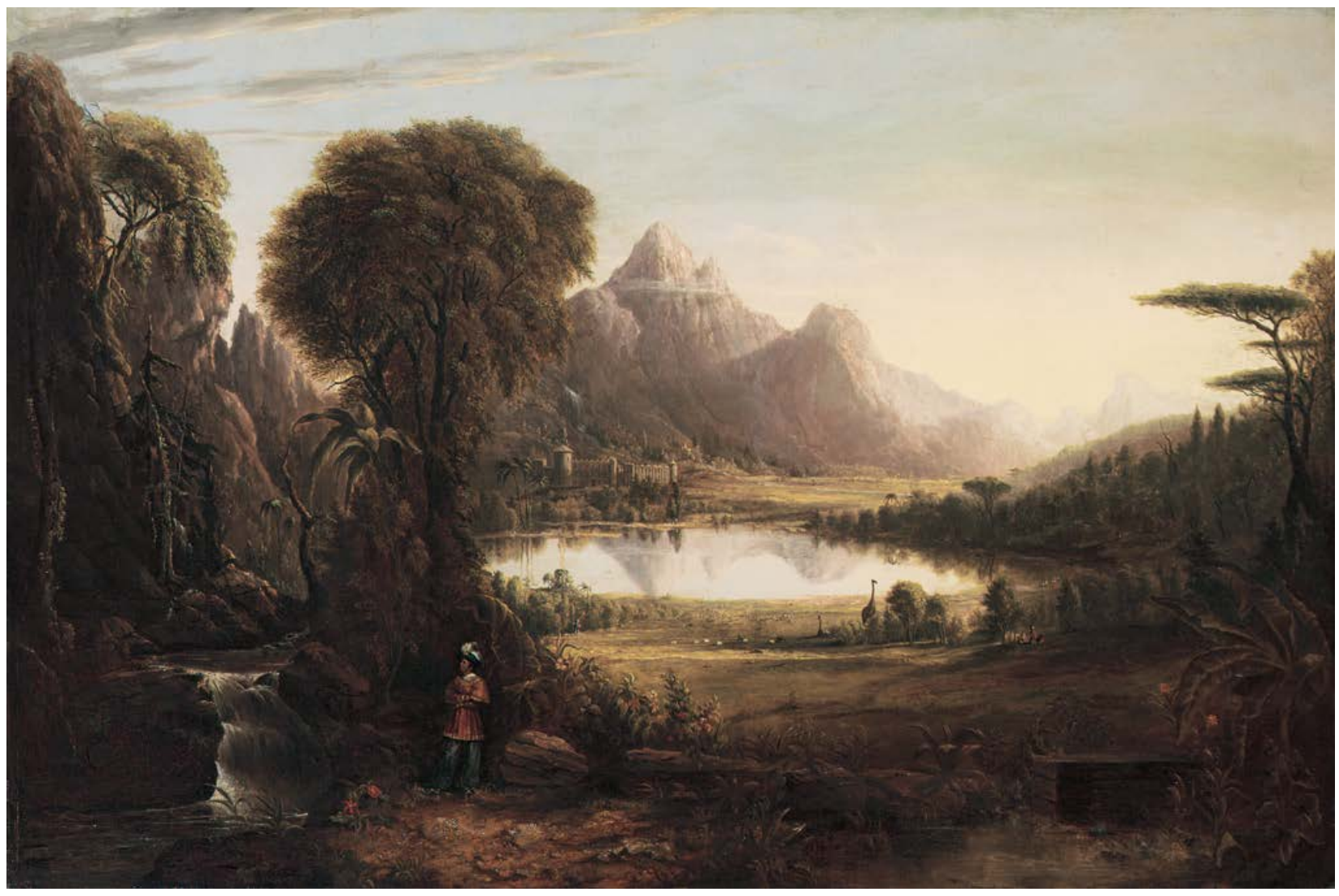

Figure 6: Jesse Talbot, The Happy Valley, from Rasselas, the Prince Meditating His Escape, 1841, oil on canvas, $48 \times 72$ in. Private collection. Photo (C) Christie's Images/Bridgeman Images.

ideals of American landscape painting as developed by Thomas Cole, the widely acknowledged star and innovator of this genre, and promoted by the National Academy. A writer for the Spectator began his preview of the original oil painting of Rockland Lake, presumably viewed in Talbot's studio, by making a direct comparison between Talbot and Thomas Cole, advising the latter to "have a care, or he will have an aspirant by the side of him in his own peculiar art before he is aware of it." 30

It is not known what Cole might have thought of such a comparison-if he "had a care" at all-but it does seem that the reviewer's remarks may have nurtured Talbot's aspirations. In the National Academy's 1841 exhibition he showed another painting, The Happy Valley, that drew additional comparisons to Cole (figure 6). A reviewer for the New York Mirror wrote of The Happy Valley that "at first sight we took this picture for one of Cole's" and noted approvingly that its "atmosphere and water [are] warm and transparent." 31 
The subject was an ambitious one, derived from Samuel Johnson's 1759 apologue, Rasselas, about a fictional prince of Abyssinia. The Happy Valley is an earthly paradise in which Rasselas is nevertheless bored and unhappy, but to which he can never return if he decides to leave it. There is an obvious thematic connection to both The Pilgrim's Progress and to the biblical subject of the garden of Eden, which Cole had treated in two already canonic paintings some twelve years before; ${ }^{32}$ the canvas represents Talbot's first foray into the literary/allegorical landscape genre at which Cole excelled. Within only two or three years of dedicating himself to the fine arts, Talbot was not only completing such ambitious works but also receiving individual praise of the highest order: a positive comparison to Thomas Cole. Years later, Walt Whitman would claim that The Happy Valley was the first painting by Talbot that caught his eye. ${ }^{33}$

Notably, the 1841 National Academy exhibition that featured The Happy Valley also provided the premier venue for Daniel Huntington's influential and much-praised Mercy's Dream (figure 7), a scene from The Pilgrim's Progress. Huntington's affecting canvas - it was described as "transcendently beautiful" by one critic ${ }^{34}$ - seems to have provided a genesis for the many additional Bunyanthemed paintings by Academy painters in the 1840s, including Talbot's 1847 Christian at the Cross. In this context, but also more broadly, Talbot's exhibition history and critical reception continually intertwined with those of Huntington and Cole. Both, unlike Talbot, represented the art establishment of the time: Cole was a founder of the National Academy, and the Yale-educated Huntington had been elected a full member in 1840 at just twenty-four years old. ${ }^{35}$ Their credentials stand in stark contrast to the scrappier origins and more irregular rise of Jesse Talbot. Whatever Cole, Huntington, and other National Academy insiders thought of Talbot's paintings, they must have found it disorienting to see the culminating works of their years of dedication and study share wall space and praise with those of an upstart tract distributor.

The critics' tendency to frame artistic achievement as a zero-sum, entrepreneurial game may have thrown such distinctions into high relief and allowed rivalries to fester. Much of this criticism reflected the contemporary debate among critics, artists, and other observers of culture about whether American art, particularly landscape painting, should be more "natural" or more "ideal" - a binary opposition that was roughly equivalent to a distinction between "American" and "foreign" that was happening in literature as well as art at the time. ${ }^{36}$ Charles Briggs and a core group of critics, mostly associated with populist, Whig-owned newspapers, concurred that American landscape painters should look to nature, rather than to tired European academic tradi- 
WWQR Vol. 38 No. 1 (SUMMER 2020)

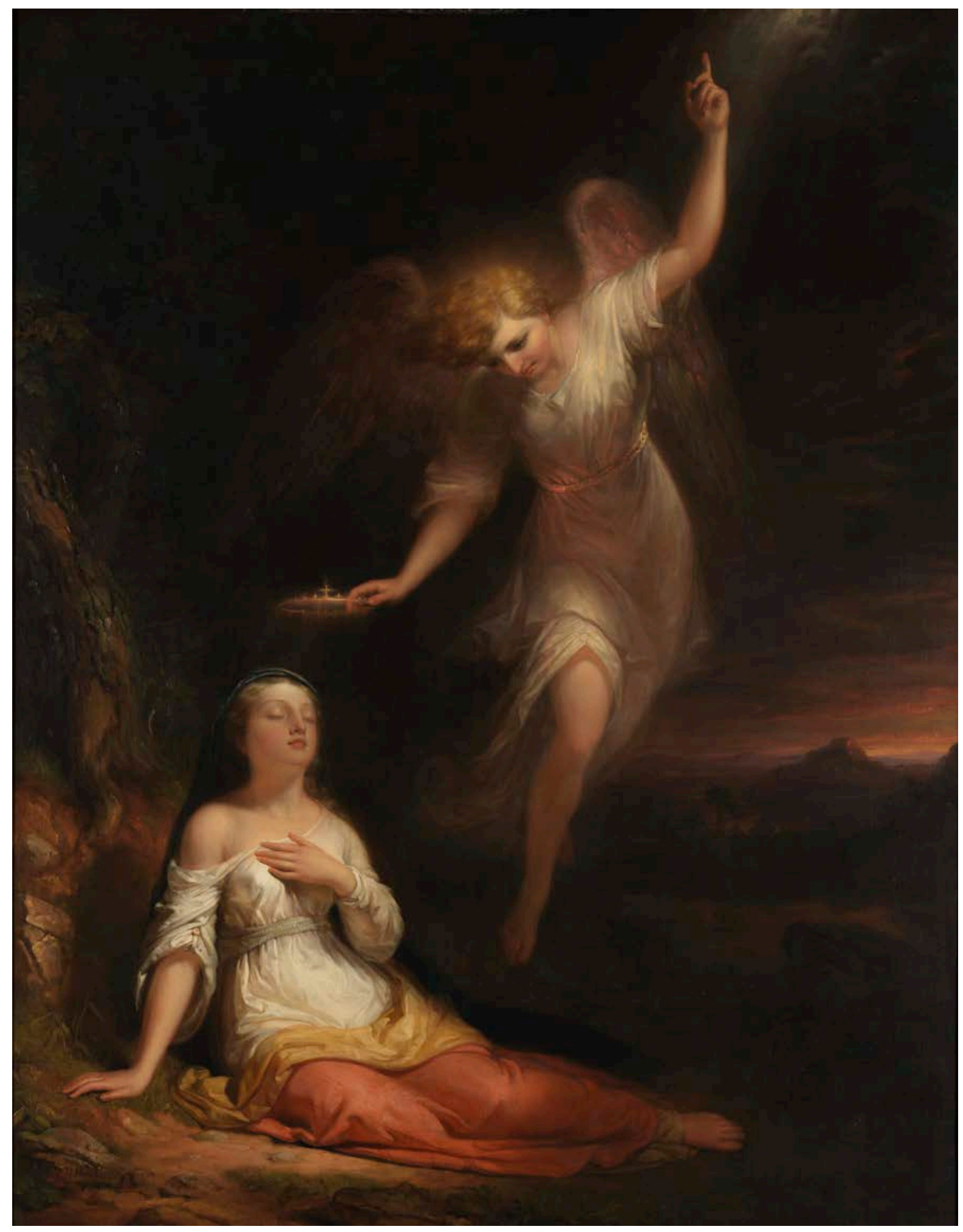

Figure 7: Daniel Huntington (American, 1816 - 1906), Mercy's Dream, 1841, oil on canvas, $845 / 8 \times 661 / 2$ in. Courtesy of the Pennsylvania Academy of the Fine Arts, Philadelphia. Bequest of Henry C. Carey (The Carey Collection). 
tions, for guidance and inspiration. ${ }^{37}$ On the other hand, critics for opposing Democratic papers bemoaned the lack of quality and distinction in American art and exhorted painters to reach beyond the banalities of the everyday for their subjects and effects.

These were surely the maligned "connoisseurs" that were in Walt Whitman's crosshairs in the article he wrote for Briggs's Broadway fournal in 1845, "Art-singing and Heart-singing." 38 Although the art Whitman discussed was of the musical rather than the visual variety, his words nevertheless make clear that he advocated for a kind of artistic expression that was new, natural, and uniquely American - and that he scorned those whose preferences differed. "We have long enough followed obedient and child-like in the track of the Old World," he wrote. The new American arts must "supplant the stale, secondhand, foreign method, with its flourishes, its ridiculous sentimentality, its anti-republican spirit, and its sycophantic influence, tainting the young taste of the republic."

Whitman was at this time beginning to write frequently about the arts for various New York and Brooklyn newspapers, including the Brooklyn Evening Star and the Brooklyn Daily Eagle, both of which he edited for brief periods between 1845 and $1848 .{ }^{39}$ His opinions are passionate, unmediated, and absolutely consistent. Beyond promoting a specific brand of republican-hued American art generally, he also made clear the fact that Brooklyn artists were particularly admirable and authentic and praiseworthy - and, needless to say, undervalued by the reigning New York art establishment.

Brooklyn would one day be the arena for the friendship between Jesse Talbot and Walt Whitman - but that day would have to wait. Just as Whitman was wading into the treacherous waters of cultural criticism in antebellum New York, Talbot was temporarily taking refuge from it. In 1844 Talbot moved to Paterson, New Jersey, an industrial town about twenty miles outside of Manhattan, situated on the falls of the Passaic River. ${ }^{40}$ The reasons for the move, just as Talbot's artistic career was taking off, are not clear. Talbot and his wife had recently lost two young sons, presumably to disease, so it could be that they sought to leave the squalor of the city. ${ }^{41}$ But it is also possible that the city held additional dangers.

Thus far we have had some success in treading through Talbot's biography and cultivating a sense of who he was as a professional-first a missionary and then a painter, first Massachusetts, then New York, then New Jersey. Less easily determined is a sense of who he was as a man, and again, the dearth of sources in his own voice is a disadvantage. A few passages in the words of others provide 
hints but no clear picture-the Knickerbocker described him as "diminutive"; the New York Herald said he was "tall and gaunt." 42 Whitman and others who spent time with him in the 1850s suggest an agreeable sort of person: humble and diffident, a genial host. ${ }^{43}$ But we should temper this perception with the knowledge of some posthumous remarks about Talbot's lack of discipline that may be coded language for a darker sort of failure in self-governance.

In memorial remarks that he made shortly after Talbot's 1879 death, Daniel Huntington, then president of the National Academy, said that Talbot's "first brilliant promise as an Amateur was not fulfilled in later years from the lack of severe discipline." ${ }^{\prime 4}$ It is certainly possible that Huntington was talking about discipline only in the context of artistic practice. However, a diary entry from landscape painter Jervis McEntee from the day of Talbot's funeral makes it clear that the perception of Talbot at the time of his death was of a man who had squandered more than just his artistic opportunities. McEntee wrote, with evident surprise: "There were quite a number of very nice looking people at the funeral. I feared there would be but few." ${ }^{\prime 5} \mathrm{He}$ was also somewhat relieved to find that "the house looked poor enough but much better than I feared it would." McEntee also remembered that Huntington offered to help defray funeral expenses on behalf of the Academy, and there is evidence that he did indeed do so. ${ }^{46}$

The problem may have been alcohol, possibly combined with other vices that often accompany its abuse. It seems a bold thing to levy such an accusation 140 years after the fact, and yet the evidence is there. The painter Jasper Francis Cropsey visited Talbot in Paterson in 1846 and, recalling the trip later in a letter to his fiancée, called Talbot one of the "drunkest men in Passaic [County]." 47 There are other, more circumstantial, hints as well. Talbot changed studio locations frequently throughout his career, with stints at prestigious addresses like New York University, Post's Buildings, and Dodworth's. ${ }^{48}$ But in 1858, city directories gave his studio location as 600 Broadway, an infamous address that was, at that very time, the location of a brothel known as "Gaieties," which offered an array of pleasures and boasted of its "pretty waiter girls." 49 This is not outright evidence of any kind of indiscretion, but it certainly demonstrates the close proximity of Broadway's temptations to Talbot's everyday life.

A love of alcoholic spirits was in direct conflict with Talbot's faith. The temperance movement in America was closely associated with evangelical Christianity, ${ }^{50}$ and Talbot would surely have understood moderation, if not total abstinence from alcohol, to be a moral and spiritual standard that he as a Christian man was obliged to uphold. There is ample evidence that, both 
through the Tract Society and through his membership in the First Presbyterian church in Paterson, Talbot conducted what we would today term interventions with parishioners who struggled with alcohol-and his involvement in this specific kind of ministry supports a theory that he himself knew the challenges of addiction. ${ }^{51}$

Viewed in this light, Talbot's Christian at the Cross, which he completed in Paterson $^{52}$ and exhibited at the National Academy and the American Art-Union in 1847, may have special significance. The scene is a centrally important one in Part One of The Pilgrim's Progress: the moment at which Christian fully invests himself in his journey along the "narrow path," or the "King's highway," as Bunyan refers to it, and accepts the obligations that go with it. For the first part of Christian's journey, he is compelled to travel with "a great burden upon his back," a physical manifestation of his burden of sin. It is only when he reaches a walled-in area of the path called "Salvation," and follows it to a hilltop where there is a cross, that his burden of sin falls from his back into the sepulcher below. Bunyan's point, although framed in allegory, is unambiguous: those who are burdened by sin must humble themselves before a higher power in order to be redeemed. If Talbot himself struggled with alcohol abuse or other vices, and if his faith had helped him to overcome his weaknesses-or if it simply offered the promise of one day doing so-the subject may have been deeply personal.

Of course, the subject was politic, as well. It gave Talbot an opportunity to capitalize on the popularity of Huntington's earlier Pilgrim's Progress-themed work, Mercy's Dream, which had received such lavish praise in the press. Talbot's work was similarly well received when it was shown at the National Academy, with more than one critic praising it, and Talbot, at the expense of others whose work was on view. The Knickerbocker wrote that "we have seen nothing from [Talbot's] pencil to compare with his Christian and the Cross" before taking a $\mathrm{jab}$ at the other exhibitors, encouraging Talbot to "leave imitations of particular schools and particular artists to less original and capable painters." 53 The writer, probably Lewis Gaylord Clark, closed with a pun on Talbot's name, a combative phrase meaning, essentially, "give 'em hell": "No matter whether critics or brother-artists praise or blame; do you 'give 'em JESSE', and that will suffice." It's unclear whether Clark was actively trying to engineer a rivalry or was merely stoking the fires of what already existed.

Paintings inspired by The Pilgrim's Progress were thick on the ground in the late 1840s, with new works by Huntington, Frederic Edwin Church, and Edward Harrison May in addition to Talbot's; Talbot's second painting on the theme, the Departure of Christian from the Palace, Called Beautiful, as well as 
another painting by Church, appeared in the National Academy annual of 1849 . (Of these, only Huntington's works and the two earlier canvases by Talbot and Church are known today.) It would shortly become public knowledge that many of the very artists who were painting scenes from The Pilgrim's Progress were also developing plans to produce a moving panorama of the same subject. The first official notice appeared in the August 1850 Bulletin of the American Art-Union; however, subsequent reports dated the panorama's genesis back to the winter of 1848, when Talbot was painting Pilgrim's Progress scenes along with everybody else. ${ }^{54}$ But where Huntington, Church, May, and others ended up being formally credited with designs for the panorama and enjoyed enhanced visibility and critical attention because of it, ${ }^{55}$ Talbot was not.

We have already looked at some of the class distinctions, controversies, and personal conflicts that might partially explain this. But it's worth digging a little deeper here. We have already discussed how the debate over the "natural/ American" versus the "ideal/foreign" made this a contentious time for American art across media, and we saw Whitman offer his own two cents in his "Art-Singing and Heart-Singing" article. In the visual arts, these lines were drawn, to some extent, between the National Academy, which espoused a traditional European approach to art production and display, and the American Art-Union, which offered itself as a more populist alternative, with a complicated lottery system of art distribution.

Ultimately, controversy over the Art-Union's selection process and business practices led to its gradual downfall, beginning around 1848 and ending with its dissolution four years later. ${ }^{56}$ Talbot had been heavily invested in the Art Union, although he showed work at both institutions. ${ }^{57}$ But after the first public murmurings of discontent, he never again exhibited there and instead recommitted himself to creating work for submission to the National Academy's annual shows. It was the only reasonable decision to make, since the National Academy would soon be the only game in town-but as Talbot went on to suffer various career disappointments at the hands of the Academy, he surely mourned the loss of the somewhat more welcoming Art-Union.

This is the point at which Walt Whitman reenters our story. By the end of 1848, Talbot and Whitman were both back in New York-Talbot having alighted from Paterson and Whitman recently returned from New Orleansand by 1850 they were both in Brooklyn, although Talbot maintained a studio in Post's Buildings in Manhattan. ${ }^{58}$ Thanks to Whitman, their friendship is documented in the pages of the New York newspapers. Whitman wrote about Talbot three times in 1850, once a brief account of visiting the artist's third- 
story studio at Post's; once as part of a review of the new Brooklyn Art-Union; and once a lengthy encomium entitled "American Art-Jesse Talbot." 59

The latter, written for the May 19 New York Sunday Dispatch, takes the form of a retrospective of Talbot's career to date. While ardent in its praise, it also seems to address obliquely the reality of some career disappointments on Talbot's part. Whitman traces his interest in Talbot back to the 1841 display of The Happy Valley, writing of it that "Nature is full of glowing blood-Earth throws out her vitality in manifold and most delicious forms," and mentions other key works, including Rockland Lake, before going on to write: "Two very beautiful works of Mr. Talbot's that gained the approval of the most fastidious, and the popular voice too, are a couple of ideas from Pilgrim's Progress, 'Christian and [sic] the Cross' and 'Departure of Christian from Palace Beautiful,' exhibited, we believe by the National Academy some years since."

The reference to these works and their connection to the Academy seems pointed. The Moving Panorama of Pilgrim's Progress, that massive undertaking of Academy insiders, would be announced to the public just three months hence, in the August 1850 issue of the Bulletin of the American Art-Union, and just three months after that the panorama would debut at New York's Washington Hall to widespread critical and popular acclaim. ${ }^{60}$ In other words, the project was already well underway at the time that Whitman's article appeared. Talbot would have known this, and through him Whitman would have known it, too. Whitman's article is a cautiously worded reminder that Talbot was an early innovator of the theme and that he did so within the bounds of the Academy and with wide popular and critical support.

The article reflects Whitman's participation in what Jason Stacy has described as "an age of unrivaled puffery"; ${ }^{61}$ it was clearly meant to promote Talbot and place him at an advantage relative to competitors. Less clear, however, is whether the immediate intent (presumably a collaborative one between Whitman and Talbot) was a last-minute effort to persuade the panorama's showrunners, Joseph Kyle and Edward Harrison May, to invite Talbot to design a scene for the panorama, or to condemn a decision that had already been made to exclude him.

Either way, Whitman's declaration that Talbot's paintings had received critical as well as popular acclaim could have also been a poke at Church, whose Christian at the Borders of the Valley of the Shadow of Death had been nowhere near as well received as Talbot's Pilgrim's Progress paintings but was adapted for the panorama nonetheless. Whitman goes to some pains to describe Talbot as "one of the most modest and the least 'pushing' of all of our artists"-implying 
some deficiency of these qualities in others-and also pays him the now-familiar compliment of allegiance to "the great source of Art and Beauty, Nature herself." 62 Explaining how Talbot spent "months and months" studying nature and "transferring [it] to his canvas," he adds, "We are sure that this is better than even 'visiting Europe." This is as close as the article comes to a direct insult, here levied at Huntington, who had recently traveled to Europe and received some grief for it in the press.

It was a risky gambit that did not pay off; the panorama debuted in November 1850 without Talbot's involvement. The article also did not obviously increase affection between Talbot and the National Academy of Design. With no works on view that year at either the Academy or the Art-Union (which he had broken with two years earlier), he was more or less absent from the scene. As a result, his notices in the press were limited largely to Whitman's three pieces as well as a brief mention in the Home fournal of December 28: "Mr. Talbot is busy at his easel. . . . We have seen none of this gentleman's work abroad [i.e., around] for a long time, and hence conclude that he is busily employed on commissions. We hope it is so." ${ }^{63}$

In this light, it is possible to view Whitman's articles about Talbot in the 1850 s as a by-product of an overall publicity campaign, one that, in some sense, had two authors rather than one. The words were Whitman's and the sentiments expressed were in firm alignment with Whitman's long-established views of art in America and in New York. What is new is Whitman's promotion of Talbot as the model artist of the time and his acceptance of his friend's grievances and disappointments as his own.

The friendship was a real one and not just for the papers. If nothing else, Whitman's notation of Talbot's name and address in the inside front cover of the Talbot Wilson notebook demonstrates their intimacy to the extent that Whitman visited the Talbot family home on Brooklyn's Wilson Street (figure 8). But there is also a more direct and detailed account of such a visit from Talbot's eldest daughter, Mary Augusta Burhans (who has erroneously-and understandably, given her eccentric penmanship - been identified as a "Mrs. Buckny" by previous scholars). ${ }^{64}$ Years later, as Whitman lay dying in New Jersey-and as the final days of his life were recorded in the newspapers-Mrs. Burhans wrote to the Good Gray Poet and reminisced (figure 9):

I carefully read the long article in the "Herald" drawing a clear cut picture of the [first] thirty five years of your life, and found my self weeping at the close-for it brought back as plainly as if but yesterday my earliest recollection of yourself in connection with my father, and "dear Old Brooklyn." 
Believe me Honored Sir, I can see the Yorkville Stage stopping at our door pleasant summer afternoons in 1852 and Walt Whitman and Jesse Talbot getting down from the upper most [stage?] and then the long and instructive chats, over good coffee, and paintings. ...

You I think, fully understand my father-the American people have yet to learn his real merit. I have deeply studied Art and find his best works all stand the best. ${ }^{65}$

The letter allows present-day scholars to construct a compelling picture of these two men-one blessed with manly beauty and still young at thirty-three; the other "gaunt" and well into middle age at forty-seven-accompanying each other on Manhattan adventures and then rehashing everything in front of the older man's Brooklyn home-fire. Their "instructive chats" would probably have included talk of the politics of the New York art world, and perhaps some strategizing of the type that seems to have informed Whitman's contemporaneous articles about Talbot. Beyond that, it is also appealing to imagine that these two men shared their mutual views about the responsibilities and rare opportunities related to being citizens of New York, of America, and of the world.

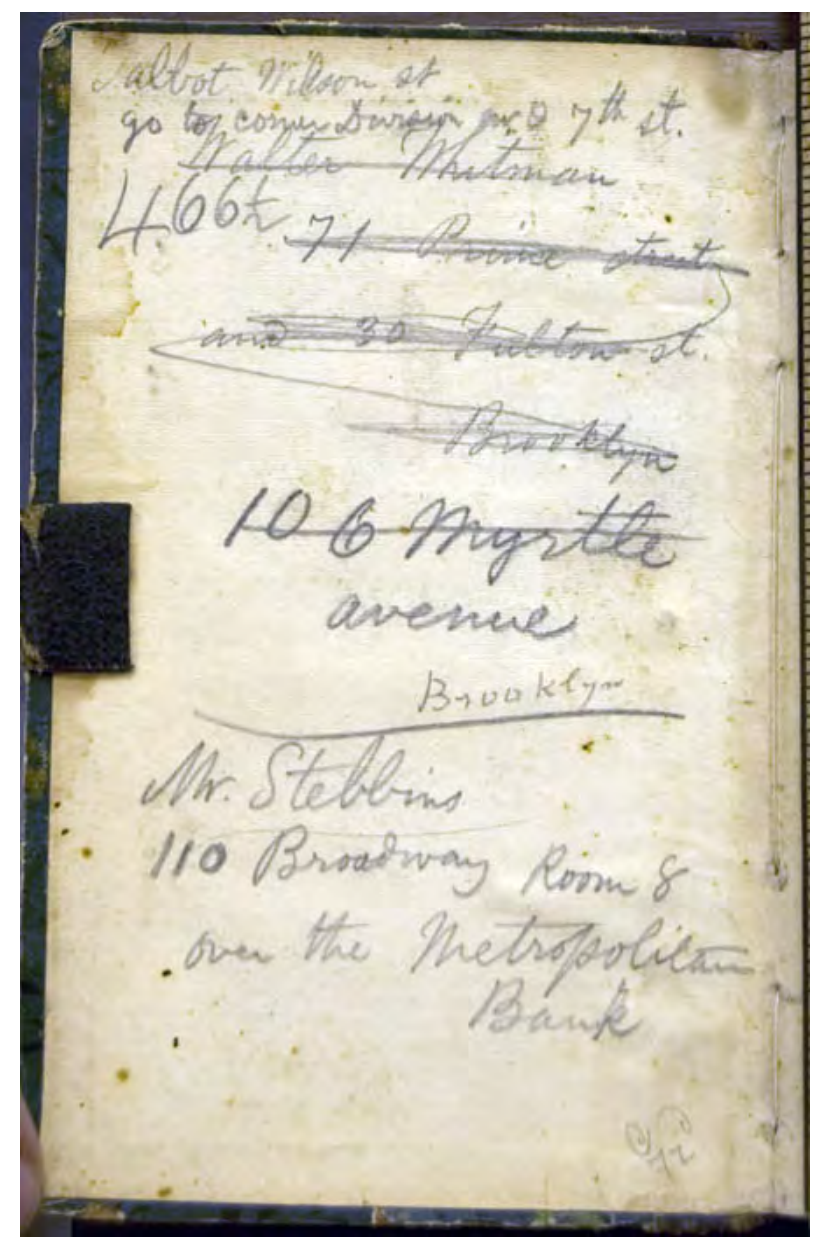

Figure 8: Talbot Wilson notebook, inside front cover. Notebook LC \#80, The Thomas Biggs Harned Collection of the Papers of Walt Whitman, 1842-1937, Library of Congress, Washington, D.C. Available on the Walt Whitman Archive. 
WWQR Vol. 38 No. 1 (SUMMER 2020)
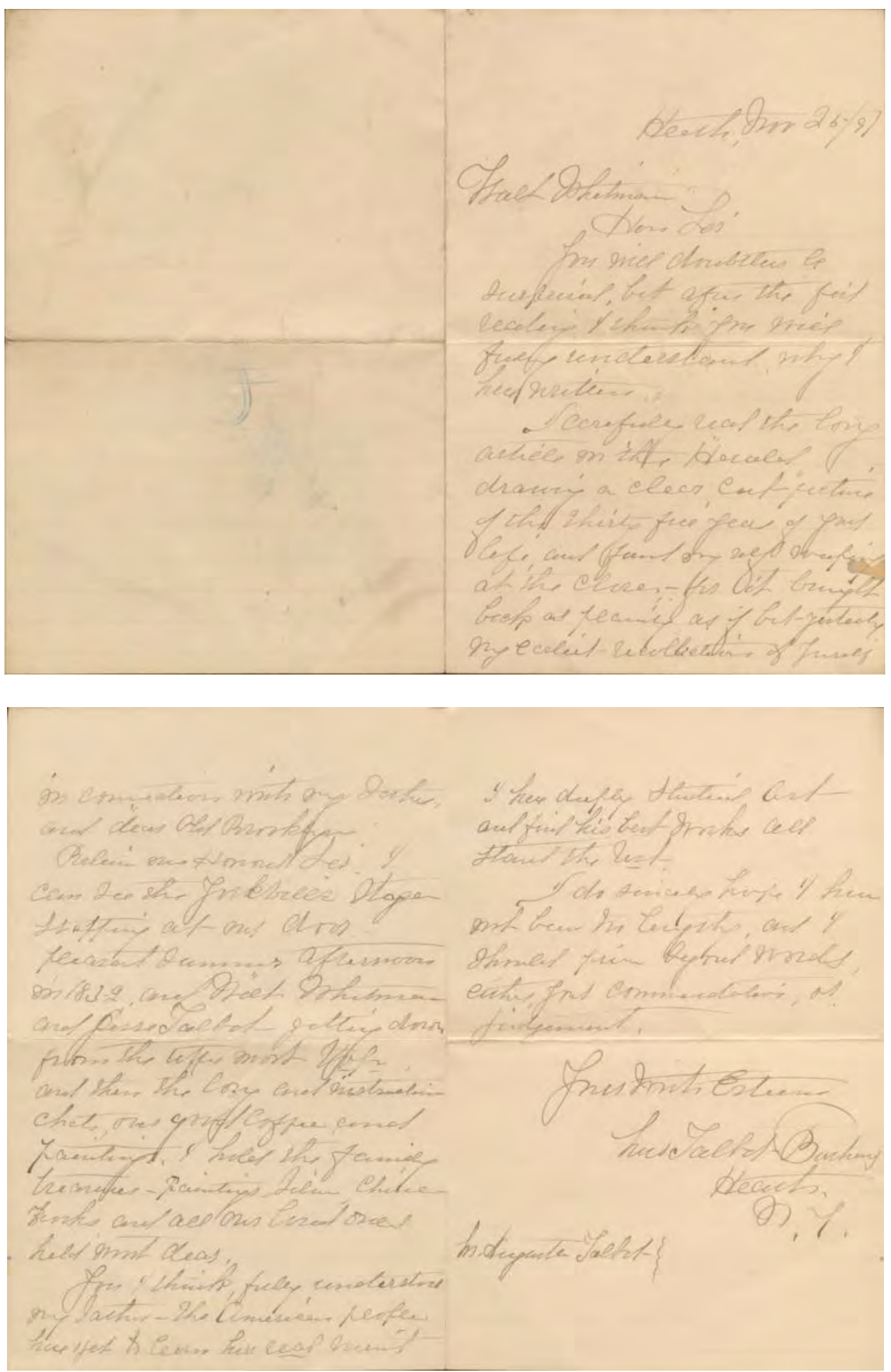

Figure 9: Mrs. Talbot Burhans to Walt Whitman, November 25, 1891, Whitman-Feinberg collection, Library of Congress, reel 2. 
Both men's thoughts on this broad subject had been evolving over a period of years, beginning with their shared early beginnings in the print shop and continuing through what they learned and adapted from each other. Talbot's engagement with such Whitman-esque ideals of individuality, authenticity, and advocacy, albeit in a specifically Christian context, are already evident in his previously quoted minutes for the tenth annual meeting of the New-York Tract Society, from 1836: "Christianity has made a kind of republicanism unknown in classic lands," Talbot writes, "but Christianity has no magic by which it operates, independently of the laws of the mind." The argument is one in favor of not just believing but also doing, of taking lofty ideals and living them in the real world. Regarding the poor, his exhortation is to "Go to them and bless them."

As many scholars have noted, Whitman would adopt the rhetorical style of the pulpit in Leaves of Grass, whose 1855 prologue positions the author as a kind of secular preacher:

This is what you shall do: Love the earth and sun and the animals, despise riches, give alms to every one that asks, stand up for the stupid and crazy, devote your income and labor to others, hate tyrants, argue not concerning God, have patience and indulgence toward the people, take off your hat to nothing known or unknown or to any man or number of men, go freely with powerful uneducated persons and with the young and with the mothers of families, read these leaves in the open air every season of every year of your life, re-examine all you have been told at school or church or in any book, dismiss whatever insults your own soul, and your very flesh shall be a great poem. ${ }^{67}$

We have already noted how in this, his opening salvo as a major poet, Whitman puns on the word "leaves," referring to both blades of grass and the pages of his book, just as Talbot years before had likened the Tract Society's publications program to the Tree of Life in The Pilgrim's Progress, whose "leaves are for the healing of the people." Both men tied their ministries to semi-sacred texts - religious tracts and The Pilgrim's Progress, in Talbot's case, and his own volume of poetry, in Whitman's - which they in turn connected to the natural world through the same punning analogy. Further, both men's artistic outputs argue for an outward existence that honors the inner life of the soul, and they express the nature of that existence not as a fixed state of being but as a journey, a pilgrimage. It was most likely during the course of their friendship that Whitman wrote, in the notebook that bears Talbot's name, "I will hook my left arm around your waist till I point you to the road along which are the cities of all living philosophy and pleasure. Not I, not God can travel this road for you. - It is not far, it is within the stretch of your thumb. Perhaps you shall find you are on it already, and did not know" (figure 10). ${ }^{68}$ 

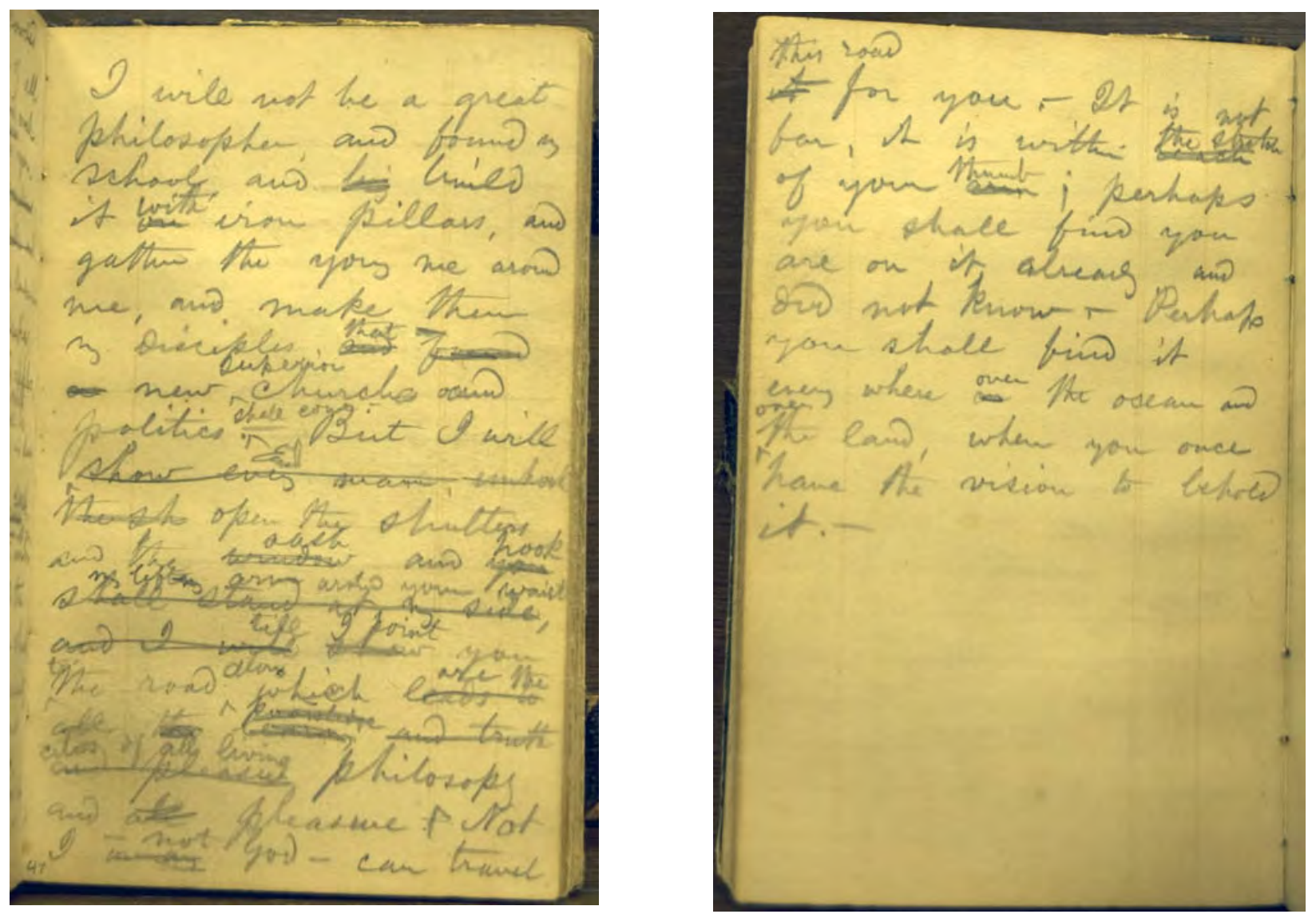

Figure 10: Talbot Wilson notebook, folio 25, recto and verso. Available on the Walt Whitman Archive.

Little wonder, then, that Whitman came to own a version of Talbot's Christian at the Cross, in which ideas of body, spirit, and pilgrimage come together. Whitman acquired the painting, which could have been made especially for him, sometime before February 1853, when he referred to it in another piece of Talbot apologetics, this time in the American Phrenological Fournal. "Christian and [sic] the Cross is another warm and glowing work by Talbot, in the possession of Walter Whitman, of Brooklyn," he writes, under a thin veil of anonymity. "It has some exquisite touches of color and delicate outlines. The large picture, of which it is a reproduction, in smaller size, equally delighted the critics and the public, on its first appearance some years ago." ${ }^{69}$ This description, in addition to a later letter to a creditor in which he refers to the painting as "an oil painting, an original" by Talbot, should lay to rest previous scholars' arguments that what Whitman owned was an engraved print of this subject by Talbot. ${ }^{70}$ No such engraving was ever produced, and so it seems indisputable that Whitman owned 
a smaller oil version of the painting that exists today, which is surely the original canvas shown at the National Academy in $1847 .^{71}$

At any rate, here again, the reference to the original painting's debut and widespread acclaim demonstrates that Talbot's talent had been universally acknowledged, so if he was now being excluded it was through no fault of his own. Indeed, the Phrenological fournal article begins with a complaint of injustice: "One of the New York journals speaks of a new work by Jesse Talbot, 'The Encampment on the Desert,' and regrets that it was not procured for the recent exhibition of the National Academy." In writing this, Whitman once again third-persons himself, for as Wendy Katz has recently confirmed, he was the one to express that initial regret nearly a year before. "Why was not Talbot's 'Encampment of the Desert' and other lately finished work of the highest class in art . . . secured for this Exhibition?" he had groused (as "W.W.") in the April 25, 1852 issue of the New-York Sunday Dispatch. ${ }^{72}$ That reference recalls an even earlier piece by Whitman, who under the single initial "W." printed an extended, complimentary account of the painting (currently unlocated), then still at Talbot's easel, in the 1851 New-York Evening Post, presumably in the hopes that the Academy, or a private collector, would take notice. ${ }^{73}$

"It is a picture with camels," Whitman begins somewhat prosaically, but then he fully deploys his gifts of persuasive rhetoric. He lavishes particular attention on the "oriental" features of the scene, dwelling on the tents, the camels, and particularly the banana trees: "Long, long and lingeringly will the eye remain on these beautiful trees, on their slender stems, and on their broad leaves, an effusion of the royal richness of the drapery of nature." Whitman's enthusiastic prose reflects his well-documented interest in the Near East ${ }^{74}$ and also resonates with the prominent-and indeed "supple" and "vigorous" palms in Tropical Scenery - Early Morning, made around the same time. We can discern in Tropical Scenery some of the same aesthetic qualities that Whitman praised in Encampment, including an "effect" that, by now, more critics than just Whitman had identified as "a distinctive mark of this artist . . . a likeness of air in the picture: palpable, yet clear sun-warmed air." 75 This and other aspects of the picture, Whitman wrote, were not likely to "be surpassed by any living artist."

Having mounted such lavish praise on Encampment, Whitman was probably offended on his own behalf as well as his friend's when it was not selected for the 1852 exhibition at the National Academy. Using the same strategy that the artist Thomas P. Whitley had deployed against the Art-Union two years earlier ${ }^{76}$ Whitman magnified an individual complaint into evidence of widescale failures endemic in the organization. Whitman accused the Academy lead- 
ership of being "too lazy" and standing "on the stilts of its own dignity."77 "It is not a favor at all for you to give audience to a superior performance of a genuine artist," he wrote, referring to Talbot, "it is rather a piece of grace on the part of the painter." The Academy's failure to recognize this, he argued, had led to the observed "deficiency of fervor and warmth" in the works on view in the current exhibition. "Many of the pictures are coldly correct," he wrote, "but the blood in their veins moves by rote; and $\mathrm{O}$, so languidly - so tamely. We would have it in jets from the heart-in spasms, if you please-only the real scarlet, charged, to the full."

Impossible to ignore here is the resonance with Whitman's lines from "I Sing the Body Electric" as they appear in the 1855 edition of Leaves of Grass:

Within there runs his blood .... the same old blood . . the same red running blood;

There swells and jets his heart ... . There all passions and desires . . all reachings and aspirations:

Do you think they are not there because they are not expressed in parlors and lecture-rooms? ${ }^{78}$

It is beyond the scope of this paper to adequately address these words in the context of the racial politics of Whitman's time. I will only speculate that these words indicate some meaningful connection between the unnamed, imagined, enslaved man on the auction block in Whitman's poem and the specific, flesh-and-bone man who was his friend. In both cases, a man is being held up for judgment; the vital life forces that make him who he is are exploited for consumption; and those who are doing the judging and exploiting and consuming are deserving of criticism themselves.

While the time of Talbot and Whitman's relatively brief intercourseit has only been documented between 1850 and 1853-was, in retrospect, a prelude for Whitman's success (though not without some bumps in the road), it proved to be more of a denouement for Talbot's. If we accept the theory that Talbot worked with Whitman to launch a kind of publicity counter-campaign around the debut of the Moving Panorama of Pilgrim's Progress, we can also determine that it misfired and that Whitman's public advocacy ultimately did his friend no favors. (Whitman would go on to commit a similarly fatal error in the promotion of Leaves of Grass, when he used a private communication from Ralph Waldo Emerson as a public endorsement, without Emerson's permission.) ${ }^{79}$ It could not have helped that Whitman's tone, regarding Talbot, devolved from one of forceful appreciation- "Is it not indeed beautiful!"- to righteous outrage- "The Academy is in danger of falling into the serious error of not understanding its own position"- to one something like defeatism, in 
his final article dedicated to his friend, the February 1853 Phrenological fournal article-"We hope our citizens, who prize art and would patronize the true artist, will not allow his pencil to be idle or his works to remain in obscurity." 80

After all the fuss, Encampment of the Caravan did ultimately make it into the 1853 Academy exhibition. It seems plausible that its inclusion was at least indirectly related to the notoriety it gained from Whitman's articles-but if that is the case, it was a Pyrrhic victory. If nothing else, it was a tragic misstep for Talbot to set himself in opposition to the National Academy as the Art-Union was falling apart and the Academy's dominance once again became unchallenged. After the 1853 show, Talbot's work would not be seen again at the Academy again for four years, and his days of regular attention from the press were over.

By this time, it must have become clear to both men that whatever success Talbot would continue to enjoy, it would not be as a leading light of the New York art establishment; their friendship also seems to have gone fallow along with Talbot's professional reputation. Combined with whatever personal demons Talbot battled-whether substance abuse or some less definable "lack of discipline," to quote Huntington-his erratic and ill-judged self-fashioning also contributed to the long twilight of his career. Notwithstanding Whitman's assessment of him as the "least pushing" artist in his acquaintance, Talbot aggressively promoted himself from the early 1850s on. He paid for a listing (under "Painters, Landscape") in the directory for the New York Mercantile Union and, by the spring of 1851, he was advertising in the New York Post that he intended to open a "School of Art" in his new studio location at 579 Broadway, ten blocks north of the National Academy (he offered his Associate status at the Academy as a credential). ${ }^{81}$ On the one hand, by associating himself with a category of craftsmanship derided by the National Academy elite as "grosser materials" that had "always been repugnant to the American artist," 82 and, on the other hand, by exploiting his National Academy credentials in order to launch a competing art school, he attempted to claim both insider and outsider status. In both cases, it seems, his efforts were unsuccessful.

Talbot's fall was gradual. Through the 1850 s, he still was able to secure and complete several important commissions, including Tropical SceneryEarly Morning, probably made for the diplomat Joseph Nerée Balestier, ${ }^{83}$ and a two-painting series depicting the famous Phantom Ship of New Haven, made for the town's Trowbridge family (c. 1850). ${ }^{84} \mathrm{He}$ received some attentionthough rarely from the Manhattan papers-for works like On the funiata (which was engraved to accompany a text by Bayard Taylor for The Home Book of the Picturesque, another gift book); Discovery of the Hudson; Indian's Last Gaze; and a 


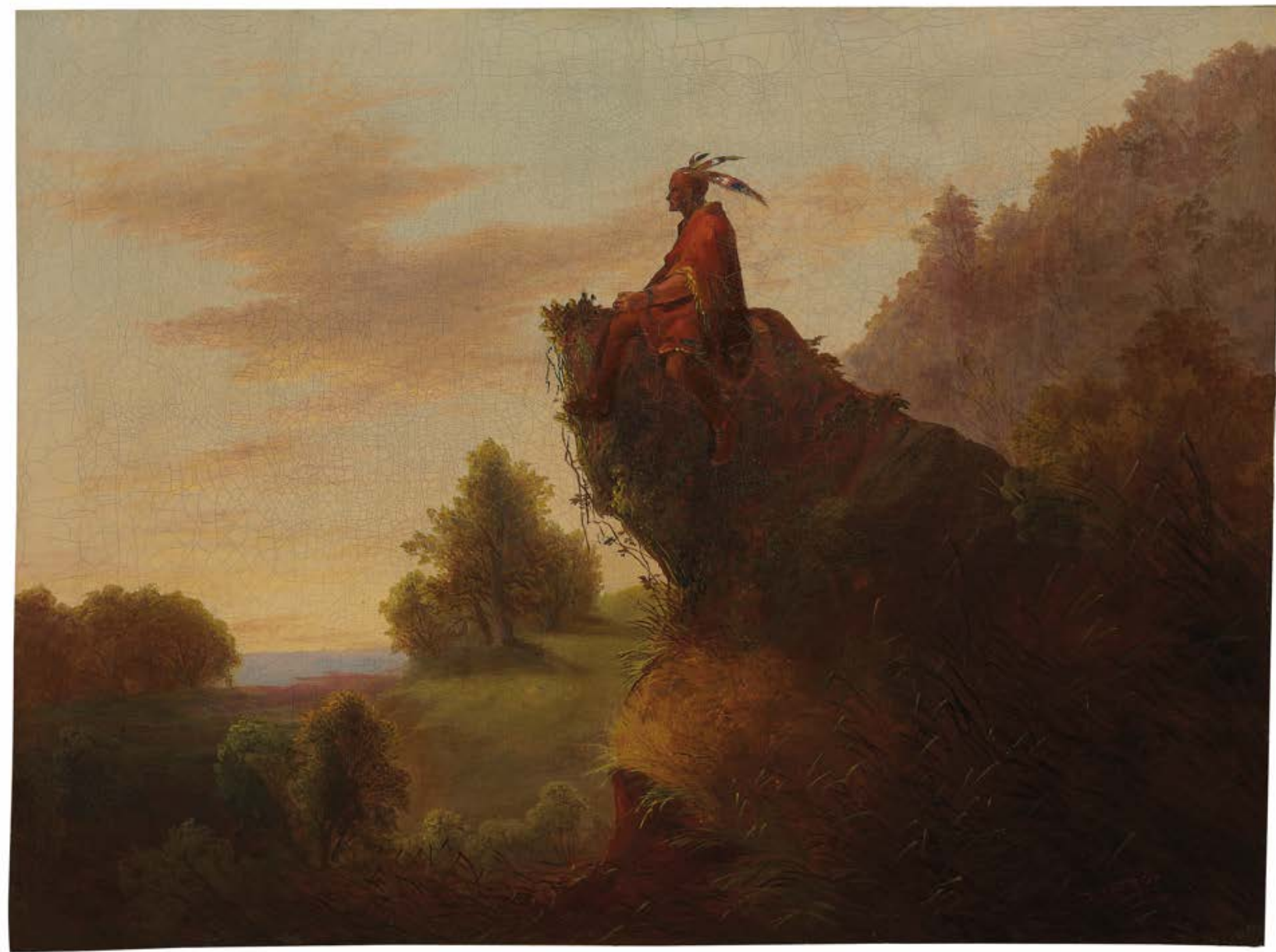

Figure 11: Jesse Talbot, The Last Gaze, 1860, oil on canvas, 18 x 24 in. Private collection. Photo (C) Christie's Images/Bridgeman Images.

biblically inspired series on the sons of Noah, which was exhibited at Brooklyn's Polytechnic Institute in $1862 .{ }^{85}$ Perhaps seeking to fill the gap left by Whitmanwith whom he had no documented contact after 1853 - he also seems to have consciously cultivated friendships with other men of letters, including Taylor and Park Benjamin, among others. ${ }^{86}$

But by the 1860 s Talbot was once again living a peripatetic existence, with home and studio addresses that changed every few years: Manhattan, Brooklyn, and Rondout, New York, in Ulster County, where he lived at least temporarily with his married daughter Mary Augusta, the one who wrote to Walt Whitman in $1893 .{ }^{87} \mathrm{He}$ still exhibited occasionally at the National Academy-his Associate status gave him that opportunity - but to the extent that he made his living as a painter, he seems to have done so primarily through small-scale compositions created on speculation - multiple variations on Indian's Last Gaze (for example, figure 11), possibly meant to depict Tecumseh looking pensively over a cliff, 
appear somewhat frequently in today's art marketplace-or exhibited and sold through the Cosmopolitan Art Association, a re-formation of the American Art-Union in Sandusky, Ohio, where the lottery laws were more lax than in New York City. ${ }^{88}$

By 1879 Talbot was back in Brooklyn, where he took his ultimately fatal fall on the ice at the corner of DeKalb and Broadway. ${ }^{89} \mathrm{He}$ was carried back to his home on Lafayette Avenue, and there, a few days later, he died. There, too- "clear out in the outskirts of Brooklyn," as Jervis McEntee wrote-his funeral was held, attended by McEntee as well Daniel Huntington, Sanford Gifford, and Richard William Hubbard, and ultimately paid for by the National Academy. He was buried in the cemetery of the Dutch Reformed Church in Claverack where he was married, alongside three of his children who predeceased him. ${ }^{90}$

The careers of Walt Whitman and Jesse Talbot ultimately led in very different directions: one light brightening as another faded; one artist mourned internationally at his death, the other pitied and all but forgotten. But during the brief time that these pilgrims' paths intertwined, they moved together toward a shared vision for American art and letters, a vision that ultimately sustained them both through long lives dedicated to their art.

\section{Association of Historians of American Art}

\section{NOTES}

This paper is derived from a talk of the same title presented at the "Walt Whitman in New York" symposium at the Grolier Club, New York, June 1, 2019, held in conjunction with International Walt Whitman Week 2019. I am grateful to Karen Karbiener and the selection committee for inviting me to present, and to the Whitman scholars who offered valuable feedback during and following that event: Eric Conrad, Betsy Erkkila, Sascha Pöhlmann, Ken Price, Zach Turpin, and Edward Whitley. My research would never have advanced far enough to have those conversations without early support and feedback from other Whitman scholars whose interests overlap with my own, and whose contributions are cited in what follows: Ruth Bohan, Jason Stacy, and especially Wendy J. Katz.

1 "Talbot Wilson" notebook, Notebook LC \#80, The Thomas Biggs Harned Collection of the Papers of Walt Whitman, 1842-1937, Library of Congress, Washington, D.C., available on the Walt Whitman Archive (www.whitmanarchive.org).

2 Some previous scholars have suggested that what Whitman owned was an engraving of the same composition produced by the American Art-Union; see Ruth L. Bohan, Looking into Walt 
Whitman: American Art, 1850-1920 (University Park: Pennsylvania State University Press, 2006), 17; and Wendy J. Katz, "Previously Undocumented Art Criticism by Walt Whitman," Walt Whitman Quarterly Review 32 (Spring 2015), 218. However, such a print apparently does not exist; see the New York Public Library's “Guide to the American Art-Union Print Collection, 1850-51," dlib.nyu. edu/findingaids/html/nyhs/artunion/bioghist.html. The confusion seems to arise from Whitman's own use of the word "reproduction" to refer to his painting in an article in the Phrenological fournal ("Talbot's Pictures," American Phrenological Fournal [February 1853], 45); however, a letter from Whitman to a creditor later in life confirms that what he owned was "an oil painting, an original, of marked beauty \& value, by Jesse Talbot, illustrating a scene from Pilgrim's Progress, worth from four to five hundred dollars." Walt Whitman to William D. O'Connor, September 28, 1869, The Charles E. Feinberg Collection of the Papers of Walt Whitman, 1839-1919, Library of Congress, Washington, D.C. (hereafter Feinberg Collection), available on the Walt Whitman Archive (www. whitmanarchive.org). The painting illustrated here is probably not the painting Whitman owned but rather "the large picture, of which it is a reproduction, in smaller size," that he refers to in the 1853 Phrenological fournal article.

3 Bohan, Looking into Walt Whitman, 17; Katz, "Previously Undocumented Art Criticism"; Katz, Humbug! The Politics of Art Criticism in New York City's Penny Press (New York: Fordham University Press, 2020), 115-118.

4 Formerly known as the York Institute, the Saco Museum is now affiliated with the Dyer Library, the public library for the City of Saco. For a history of the institution, see Kerry A. O'Brien, "ScienceArt-History: The Early Years of the York Institute, Saco, Maine, 1866-1971," Maine Historical Society Quarterly 26, no. 4 (Spring 1987).

5 The frame appears to be original to the work; it is not clear if the plaque itself is original, though it has clearly been attached to the frame for a long time.

6 Moving panoramas, popular in mid-nineteenth-century America, are unstretched paintings presented in a horizontal scroll format; they were "performed" in front of an audience, by rolling the painting from one scroll to the other, so that the depicted scenes appeared to be progressing before the viewers' eyes. Wikipedia has a useful definition and illustration: wikipedia.org/wiki/Moving_panorama. Two versions of the Moving Panorama of Pilgrim's Progress, often referred to in period accounts as "Bunyan's Tableaux" or "The Bunyan Tableaux," were produced. The first debuted in 1850 and is unlocated; the second, which is the version now at the Saco Museum, debuted in 1851. For a history of this panorama, see Thomas Hardiman Jr., "The Panorama's Progress: A History of Kyle and Dallas's Moving Panorama of Pilgrim's Progress," in Jessica Skwire Routhier, Kevin J. Avery, and Thomas Hardiman Jr., The Painters' Panorama: Narrative, Art, and Faith in the Moving Panorama of Pilgrim's Progress (Hanover: University Press of New England, 215), 89-102.

7 Details of these efforts can be found in Jessica Skwire Routhier, "Epilogue," in Routhier et al., The Painters' Panorama, 108-113; the efforts were also the subject of a paper I presented at the International Panorama Conference at Gettysburg National Military Park on September 15, 2011. For a brief video of the physical replica in motion at Saco City Hall on August 8, 2012, see youtu.be/ VNpeGSrHhp0; for an online digitization with a historic script, see youtu.be/1XMwkpnewxw (brief introduction at youtu.be/0_vkGKCOHSI); for a gallery talk in front of the original panorama, see youtu.be/OXgYkznUdXg. 
8 David B. Dearinger, ed., Paintings and Sculpture in the Collection of the National Academy of Design, Volume 1, 1826-1925 (New York and Manchester: Hudson Hills Press, 2004), 382-383.

9 I have succeeded in identifying only four pieces of correspondence in Talbot's hand: J. Talbot to W[illiam]. C[ullen]. Bryant, undated (but probably 1844-46, when Bryant was president of the American Art-Union), Bryant-Godwin Papers, box 12, New York Public Library (hereafter NYPL); J. Talbot to J[ohn]. R[ussell]. Barlett, Esq. April 14, 1847, Box 48, Ford Autograph Collection, NYPL; Jesse Talbot to T. Addison Richards, Esq., March 15, 1876, T. Addison Richards Papers, The Pennsylvania State University; and Jesse Talbot to A. J. Davis, Esq., June 5, 1876, private collection (sold through liveauctioneers, July 2018). The letters contain little of personal interest, apart from confirming that Talbot lived with his daughter Mary Augusta later in life and that she, too, had artistic ambitions (see n. 87); they are all correspondence of a professional nature.

10 "Fatal Effects of a Fall," Brooklyn Daily Eagle (January 30, 1879). Talbot fell on the ice on January 24,1879 , and died on either January 29 or January 30.

11 D. Hamilton Hurd, ed., History of Bristol County, Massachusetts, with Biographical Sketches of Many of Its Pioneers and Prominent Men (Philadelphia: J. W. Lewis \& Co., 1883), 250.

12 Vital records of Dighton and Rehoboth, Massachusetts, accessed through ancestry.com.

13 Despite the disadvantage of having, in the words of the 1854 Boston Medical and Surgical fournal, "only a limited medical education," Jesse Wheaton was appointed a surgeon in the Massachusetts militia, established a "considerable medical business" at Wheaton and Dixon on High Street in the center of Dedham Village, and even, if one can believe the broadsides, secured patents for proprietary medicines, which he offered for sale at his Dedham apothecary. "History of the Medical Profession in Norfolk County," in The Boston Medical and Surgical Fournal, ed. J.V.C. Smith, M.D., vol. 49 (Boston: David Clapp, 1854), 204. I am grateful to Sandra Waxman, Librarian/Archivist at the Dedham Historical Society and Museum, for information about the militia appointment and the location of Wheaton's store (correspondence with the author, December 22, 2015). Citations for broadsides advertising "Wheatons' genuine jaundice bitters," supposedly patented in 1799 and 1802, as well as "Wheaton's itch ointment" (1802) can be found on WorldCat.com; however, a search of US Patent records for "Jesse Wheaton" revealed no results.

14 US Census records from 1820 show a "free white male" between the ages of sixteen and twenty-six residing in Wheaton's home; this must surely be the young Jesse Talbot, although in fact he could not have been more than fifteen in 1820 (Census 1820). Wheaton did not marry until 1815, so it is unlikely that this was a child of his.

15 Other affiliations include the Norfolk [County] Auxiliary Educational Society, the American Temperance Society, the Massachusetts Society for Promoting Christian Knowledge, and the Baptist Board of Foreign Missions. Annual reports of all these organizations, which list members, donors, and their years of involvement, are easily accessible on Google Books. Wheaton's life membership in the American Tract Society is documented in the Ninth Annual Report of the American Tract Society 1823 (Andover: Printed for the Society by Flagg \& Gould, 1823), 39; however, it is important to acknowledge that this is not exactly the same American Tract Society that was centered in New York beginning in 1825 (which in turn is distinct from the New-York Tract Society, one of its auxilia- 
ries). The complicated history and interrelationship of the Boston-based New England Tract Society, which went by that name from its founding in 1814 until it was renamed the American Tract Society in 1823, and the New York-based American Tract Society, founded in 1825, is detailed in A Brief History of the American Tract Society, Instituted at Boston, 1814, and its relations to the American Tract Society at New York, instituted 1825 (Boston: T. R. Marvin, 1857). Also helpful is S. J. Wolfe, "Dating American Tract Society Publications Through 1876 from External Evidences: A Series of Tables," an online publication of the American Antiquarian Society, americanantiquarian.org/node/6693.

16 The Fourth Annual Report of the American Tract Society (New York: Printed for the Society by D. Fanshaw, 1829) lists Talbot as the "Assistant" for the Executive Committee. Additionally, the report lists Talbot as one of many "directors" on the masthead and also lists him as a member of the Shipping and Steam-Boat Committee, the City Committee, and the Division of Labor, with responsibility (with four others) for the fourth district, from Burling Slip to India Wharf.

$17 \mathrm{He}$ is also remembered as having co-founded a "Sabbath School" on Baxter Street around 1830; Rev. Moses H. Wilder, Book of the Wilders: A Contribution to the History of the Wilders (New York: Edward O. Jenkins, 1878), 27.

18 The Anti-Slavery Record of 1836 notes "Canada, a friend, per Jesse Talbot," as the source of a $\$ 25$ donation to the American Anti-Slavery Society; The Anti-Slavery Record 2, no. 8 (August 1836), 12. The Magazine of the Daughters of the Revolution 2, no. 1 (February 1896), in its listing for Talbot's wife, née Mary Augusta Sluyter, notes that her husband was "an artist of repute" who was also "one of the original Abolitionists" (219); this language is repeated in a later genealogy, Richard Wynkoop, Schuremans, of New fersey (New York: Knickerbocker Press, 1902), 95. In this the authors were probably confusing our Jesse Talbot with another by that name, a Baltimore resident who was associated with Captain Paul Cuffe, who helped to colonize Sierra Leone with freed American slaves. See H. N. Sherwood, "Paul Cuffe" in The Journal of Negro History 8, no. 2 (April 1923), 185, and, in Dorothy Sterling, Speak Out in Thunder Tones: Letters and Other Writings by Black Northerners, 1787-1865 (Boston: Da Capo Press, 1998), 48-49, a transcription of a letter from Cuffe to James Forten dated January 23, 1817, which references a "Jesse Talbot of Baltimore." Our Talbot would have been only twelve years old and living in Massachusetts at the time. For more on the connection between Christian evangelism and social justice movements in antebellum New York, see Diane Winston, Red-Hot E Righteous: The Urban Religion of the Salvation Army (Cambridge, MA: Harvard University Press, 1999), 30.

19 Ninth Annual Report of the American Tract Society (New York: Printed at the Society's House by D. Fanshawe, 1834), 23; Religious Intelligencer (May 1834), 807.

20 In 1836 and 1837, Talbot appears on the rolls of the "Receiving Agents of the Board" for the ABCFM. For an overview of the organization during Talbot's time, see New York As It Is, 6th edition (New York: T. R. Tanner, 1840), 78-79. For a broader but still contemporaneous history, see Joseph Tracy, History of the American Board of Commissioners for Foreign Missions (New York: M. W. Dodd, 1842).

21 Sluyter is listed as a member of the ABCFM board in 1835; Report of the American Board of Commissioners for Foreign Missions, Read at the Twenty-Sixth Annual Meeting (Boston: Printed for the Board by Crocker \& Brewster, 1835), 14. For a record of the marriage, see Christian Intelligencer of the 
Dutch Reformed Church, October 29, 1836.

22 Talbot's name first appears in this role in the Ninth Annual Report of the New-York Tract Society (New York: New-York Tract Society, 1836), 3. Robert's Rules of Order identify "Recording Secretary" as the proper title for the officer responsible for keeping the minutes of meetings, when there is also a "Corresponding Secretary," responsible for scheduling meetings and conducting correspondence. The report shows that one Rev. Charles Hyde served as Corresponding Secretary alongside Talbot. Roberts Rules Online, article X, item 59, "Secretary or Clerk," rulesonline.com/rror-10.htm.

23 See David E. Smith, "Publication of John Bunyan's Works in America," Bulletin of the New-York Public Library 66 (1962), and Galen K. Johnson, "The Pilgrim's Progress in the History of American Public Discourse," LATCH 4 (2011), 1-31. The description of the American Tract Society in the 1935 edition of New York As it Is (New York: J. Disturnell, 1835) lists the title among their publications, p. 62. As early as 1824, the Society published a life of John Bunyan: "The Life of Rev. John Bunyan, Author of the Pilgrim's Progress," in The Publications of the American Tract Society, 1, no. 6 (New York: The American Tract Society, 1824), 81-96.

24 "Ninth Annual Meeting," Ninth Annual Report of the New-York Tract Society, 6, 11. From The Pilgrim's Progress: "Then said Evangelist, If this be thy condition, why standest thou still? He [Christian] answered, Because I know not whither to go. Then he gave him a parchment roll, and there was written within, Flee from the wrath to come." Project Gutenberg EBook of The Pilgrim's Progress, gutenberg.org/files/131/131-h/131-h.htm. All subsequent quotes from The Pilgrim's Progress are from this source.

25 “Tenth Annual Meeting," Tenth Annual Report of the New-York Tract Society (New York: NewYork Tract Society, 1836), 10.

26 Walt Whitman, Leaves of Grass (Boston: Thayer and Eldridge, 1860), 19, available on the Walt Whitman Archive. I am grateful to Sascha Pöhlmann for bringing this passage to my attention (in the context of the so-called "deathbed edition" of 1891-92) in his concluding course lecture for International Walt Whitman Week, delivered at the Walt Whitman Birthplace State Historic Site, Huntington, New York, May 31, 2019, and for discussing it with me at the "Walt Whitman in New York" symposium at the Grolier Club the following day.

27 Mary Bartlett Cowdrey, National Academy of Design Exhibition Record, 1826-1860, vol. 2 (New York: New-York Historical Society, 1943), 150. All subsequent indications of when a work was shown at the National Academy are from this source; the source for American Art-Union exhibition records is also Cowdrey, American Academy of Fine Arts and American Art-Union Exhibition Record 1816-1852 (New York: New-York Historical Society, 1843).

28 Rev. Miron Winslow, Memoir of Mrs. Harriet Winslow, Thirteen Years a Member of the American Mission in Ceylon (New York: American Tract Society, 1840). The book had previously been printed, under varying titles, by different publishing houses in New York, Boston, and London; this is the only edition known to include Talbot's frontispiece. The book itself is typical of nineteenth-century hagiographies of missionaries, particularly female missionaries; Talbot's own daughter Blanche would one day have a similar volume written about her: Memorial of Blanche Talbot: born in Paterson, N.F., Fune 23, 1848, died in Brooklyn, N.Y., October 2, 1871 (New York: John Ross \& Col, 1873). 
29 The Token and Atlantic Souvenir, An Offering for Christmas and the New Year (Boston: David H. Williams, 1842). Talbot's engraving is accompanied by a poem of the same name by H. T. Tuckerman. For more on the Token and similar gift books, see Kristina Huff, Souvenirs of America: American Gift Books 1825-40 (master's thesis, University of Missouri-Columbia, 2006).

30 The writer describes the painting as "just completed" (begging the question of the context in which it was reportedly exhibited at the Apollo Association ten months earlier) and ends the piece by giving the location of Talbot's "room" as "the University Building," corresponding to city directory listings that show Talbot's studio location at New York University at this time. "Landscape Paintings," New-York Spectator, December 23 1840. It is noteworthy that another early notice of this painting appeared in The Evangelist, the newspaper "dedicated to revivals, doctrinal discussion, and religious intelligence generally," according to the masthead. G., "Rockland Lake," New-York Evangelist (January 25 1840).

\section{New York Mirror, May 15, 1841.}

32 For more on these, see Franklin Kelly and Claire M Barry, Thomas Cole's Paintings of Eden (Fort Worth, TX: Amon Carter Museum, 1995).

33 "Some years ago we saw for the first time 'the Happy Valley', an idea from Rasselas. . . W With one or two minor faults, it yet struck us as being a production of very remarkable beauty; and we have since kept the run of the man who did it." [Walt Whitman], "American Art-Jesse Talbot," New York Sunday Dispatch, May 19, 1850. I am grateful to Wendy Katz for providing her research photographs of this source. For more about Whitman's interest in Johnson, and some literary and biographical parallels, see Jeffrey Meyers, "Samuel Johnson and Walt Whitman," Walt Whitman Quarterly Review 26 (Spring 2009), 213-215.

34 American Repertory of Artists, Sciences and Manufactures 3, no. 5 (June 1841), quoted in William H. Gerdts, "Daniel Huntington's Mercy's Dream: A Pilgrimage through Bunyanesque Imagery," Winterthur Portfolio 14 (Summer 1979), 180.

35 For concise biographies, see "Thomas Cole: American, 1801-1848," National Gallery of Art (Washington, D.C.) website, accessed August 11, 2020, https://www.nga.gov/collection/artist-info.1155.html; and Dearinger, Paintings and Sculpture, 291-292.

36 The groundbreaking study on this is Perry Miller, The Raven and the Whale: The War of Words and Wit in the Era of Poe and Melville (New York: Harcourt, Brace \& World, 1956). A passage from the prologue, written with Herman Melville in mind, is also a useful framework for regarding the rise and fall of Talbot's career: "An artist can, once he has caught the ear of his people, abruptly discover himself cut off not because he thunders some clear sanity against their insanity, but because he participates completely in their befuddlement" (4). Wendy J. Katz also parses this conflict, specifically in the context of Talbot and Whitman, in her "Previously Undocumented Art Criticism," and more broadly in the fourth chapter, "The Penny Press's Utopian Alternative," of Humbug!, 124-125. I am grateful to Katz for sharing this chapter with me in manuscript form.

37 See Rachel N. Klein, "Art and Authority in Antebellum New York City: The Rise and Fall of the American Art-Union," The fournal of American History 81 (March 1995), 1534-1561; esp. 
1538-1540. As a particularly relevant example, Briggs wrote exasperatedly of Talbot that "If he will forget that he ever saw one of Cole's pictures, and look quietly at Nature with a clear eye, and make his own interpretations of her language, without asking the aid of any other commentator than his own heart, she will reward him as she does all who seek communion with her in the integrity of their instincts." Charles Briggs, "The Fine Arts: The Art Union Pictures," The Broadway fournal 1 (January 11, 1845), 21-22. Miller also discusses Briggs's contempt for romanticism in Raven and the Whale, 53-55.

38 Walt Whitman. "Art-Singing and Heart-Singing." The Broadway fournal 2 (Saturday, November 29, 1845), 318-319. Whitman scholar Jason Stacy has said that in his "heart-singing" article, Whitman "conflates aesthetic simplicity with personal integrity and personal integrity with American republicanism"- and so raised the stakes even further for artists who, presumably, sought to be men of honor as well as successful artists. Jason Stacy to the author, February 22, 2016.

39 A useful overview of Whitman's early art journalism is in the first chapter of Bohan, Looking into Walt Whitman, 13-29.

40 Cowdrey's National Academy of Design Exhibition Record lists his address in Paterson from 1844 through 1847 (150-151). Records of the First Presbyterian Church of Paterson show that he was elected an elder of the church on July 31, 1844, and Chairman on December 12, 1844. William Nelson, ed., The First Presbyterian Church of Paterson, New fersey (Paterson: Call Printing and Publishing Company, 1893), 66, 395. The Passaic County Historical Society's information sheet on the Talbot family shows that two of Talbot's children, Emily (b. 1843) and Arthur (b. 1846), were baptized at the church on June 16, 1844, and in 1847 (no specific date), respectively.

41 Lyman Beecher Talbot was born August 10, 1839 and died on November 29 of that year; Richard Sluyter Talbot was born December 6, 1840 and died January 11, 1843. Wynkoop, Schuremans, of Nerw fersey, 95.

42 "Editor's Table," The Knickerbocker 29 (June 1847), 571; "Exhibition of the National Academy of Design," New York Herald (April 20, 1846).

43 Whitman described him as "one of the most modest and the least 'pushing' of all our artists" in "American Art-Jesse Talbot"; the Herald reviewer who described him as "gaunt" also recalled that he "was only happy to be able to say an encouraging word to some more timid and distrustful aspirant"; a writer for the Home fournal later recalled being received cordially during a studio visit: "A few steps, and a warm welcome from the kind-hearted artist" ("Mere Mention: An Artist's Studio," Home fournal, [July 19, 1856]).

44 Minutes of the National Academy of Design, February 10, 1879, quoted in Dearinger, Paintings and Sculpture, 383.

45 Jervis McEntee Diaries, entry for January 31, 1879, Archives of American Art, Smithsonian Institution, aaa.si.edu/collection-features/jervis-mcentee-diaries/diary-entry?date $=18790131$.

46 Dearinger states this as fact: Paintings and Sculpture, 382. This is probably based on McEntee's 
later diary entry, in which he wrote that he "Went to the Council meeting" [presumably referring to a committee of the Academy], where he "appropriated $\$ 50$ towards paying Jessie [sic] Talbot's funeral expenses and reduced the commission on the sale of pictures from the Academy from 10 p. ct. to 6." Jervis McEntee Diaries, entry for February 10 1879, aaa.si.edu/collection-features/jervis-mcentee-diaries/diary-entry?date $=18790210$.

47 Jasper Francis Cropsey to Maria Cooley, November 12-17, 1846, transcription in the collections of the Newington-Cropsey Foundation. The full quote reads "Hi ho-and then it is the residence of Jesse Talbot, the artist, and one of the richest and drunkest men in Passaic." It is not clear how he meant "richest," given the numerous references to Talbot's poverty, including the American Republican's description of him as "poor but ambitious" just two years before: American Republican, May 20, 1844. It is possible that Cropsey was being ironic, in which case-it must be acknowledged-his characterization of Talbot as drunk as well as rich should be taken with a grain of salt. Cropsey was, overall, a strong supporter of Talbot; in 1845 Cropsey identified Talbot as "third in excellence" among American landscape painters, after Cole and Asher B. Durand. Jasper Francis Cropsey, "Natural Art," lecture to be given at the Art ReUnion, August 24, 1845, transcription in the collections of the Newington-Cropsey Foundation. I am grateful to Anthony Speiser for bringing these sources to my attention.

48 New York and Brooklyn city directories, 1841-1879; Cowdrey, National Academy of Design Exhibition Record, 150-151. Dodworth's is not mentioned by name, but it is associated with the address of 806 Broadway, where Talbot kept a studio in 1853.

49 Advertisement in the Sunday Herald, February 26, 1860, reproduced in "The Sabbath and German Beer Gardens," Sabbath leaflet appendix to First Five Years of the Sabbath Reform, 1857-62 (New York: Edward O. Jenkins, 1862), 3-4.

50 See Winston, Red-Hot $\mathcal{E}$ Righteous, 30.

51 See Nelson, First Presbyterian Church, 396. The minutes for December 17, 1844, state that a church committee visited a parishioner and extracted from him a "signed and handwritten promise to abstain from the use of all intoxicating liquors." When the man, one Patrick McG-, proved unable to keep this promise, church officials "resolved that the Committee be continued \& Mr. Talbot be added to it, $\&$ that each member of this Committee consider it his duty to visit this erring brother, \& converse \& pray with him as often as may be.”

52 "Paterson" is inscribed on one of the painting's stretcher bars. Email from the painting's owner to the author, June 15, 2015.

\section{3 "Editor's Table."}

54 "Chronicle of Facts and Opinions," Bulletin of the American Art-Union, 5 (August 1850), 81-84; R. J. Greenwood, A Descriptive Catalogue of the Bunyan Tableaux (Albany: J. Munsell, 1856), 2. Greenwood was more than a commentator; he was the showman who performed and promoted both versions of the panorama during its tours through the 1850 s. 
55 The others were Cropsey, Jacob Dallas, Felix Octavius Carr Darley, Peter Paul Duggan, Joseph Kyle, and Henry Courtney Selous. For more on these artists' involvement with the panorama, see Jessica Skwire Routhier, "A More Perfect View Thereof: Landscape, Religion, and the Artistic Underpinnings of the Panorama," in Routhier et al., The Painters' Panorama, 1-32.

56 This complex history is detailed in Klein, "Art and Authority."

57 By 1848 he had exhibited thirty-one works at the Art-Union (including those shown at its predecessor, the Apollo Art Association), as opposed to only nineteen at the Academy during the same period. He had literally invested in the Art-Union, as well-a "Mrs. Jesse Talbot" of Paterson, New Jersey, is listed among its subscribers in 1847; see the Transactions of the American Art-Union for the Year 1847 (New York: G. F. Nesbitt, 1848), 122.

58 This is the address given for him in the New York Mercantile Union Business Directory for 1850 under "Painters, Landscape." For two or three years, between 1848 and 1850, the precise whereabouts of Talbot and his family are unknown. The "62 White Street" that appears in the 1849 National Academy catalogue, presumably New York, could be either a home address or a studio address. His family and his permanent home, meanwhile, could have been in either New York or Brooklyn, or even still in Paterson. But by 1850, Talbot appears on the King's County census records with his wife, three children, and a servant.

59 [Walt Whitman], “April Afternoon Ramble," Brooklyn Evening Star (April 30 1850); "Works of Beauty and Talent-The New Art Union of Brooklyn," Brooklyn Daily Advertiser (April 4 1850); and "American Art-Jesse Talbot."

60 See Hardiman, “The Panorama's Progress," 94.

61 Jason Stacy to the author, February 22, 2016.

62 Whitman, "American Art-Jesse Talbot."

63 "Art and Artists," Home fournal (December 28, 1850). I am grateful to Ruth Bohan for providing her copy of this article.

64 See, for example, Bohan, Looking into Walt Whitman, 216 note 17. Bohan also notes that "Mrs. Buckny was mistaken in her recollections that the meetings took place in 1832," but close examination of the handwriting reveals that Burhans correctly referred to the summer as that of 1852 .

65 Mrs. Talbot Burhans to Walt Whitman, November 25, 1891, Feinberg Collection, reel 2 (emphasis original). The "long article in the 'Herald" that Burhans refers to is probably "Walt Whitman's Life Has Run Its Course," New York Herald (November 1, 1891), 33.

66 "Tenth Annual Meeting," 11. Kenneth M. Price asked me, at the "Whitman in New York" symposium, how we might reconcile the fact that the decidedly un-religious Whitman had such a close relationship with the ardently Christian Talbot. Beyond what I have written here, I leave fuller conjecture to more seasoned Whitman scholars; Price himself offers something of a theory in the 
second chapter, "Whitman as a Paradoxical 'Missionary to the Wounded," of his forthcoming book. I am grateful to Price for sharing this chapter with me in manuscript form. For more on Whitman's complicated relationship with organized religion, see David Kuebrich, "Religion," in J. R. LeMaster and Donald D. Kummings, eds., Walt Whitman: An Encyclopedia (New York: Garland Publishing, 1998), available on the Walt Whitman Archive).

67 Whitman, Leaves of Grass (1855), vi. Available on the Walt Whitman Archive.

68 "Talbot Wilson" notebook, folio 25 (recto and verso). I would never have known to knit together Whitman's words and multilayered edits in this seamless way; I acknowledge Eric Conrad for bringing the quote in this form to my attention in his concluding course lecture for International Walt Whitman Week (2019), delivered at the Walt Whitman Birthplace State Historic Site, Huntington, New York, May 31, 2019, and for discussing it with me after the "Walt Whitman in New York" symposium at the Grolier Club the next day.

69 [Walt Whitman], “Talbot's Pictures,” American Phrenological fournal (February 1853), 45.

70 See note 2 .

71 The location of the smaller version that Whitman owned is unknown after it left his hands. The larger exhibition picture went to one H. W. Leiter of Mansfield, Ohio, in the 1847 Art-Union lottery (Transactions of the American Art-Union, 1847, p. 33), and it has been in private hands ever since. It does not seem to have been exhibited publicly since it was seen at the Buffalo Fine Arts Academy (predecessor to the Albright-Knox) in 1863, at which time the owner was identified as C. F. S. Thomas. Current owner to the author, June 15, 2015.

72 W[alt].W[hitman]., "An Hour at the Academy of Design," New-York Sunday Dispatch (April 25 1852), transcribed in Katz, "Previously Undocumented Art Criticism," 222-224.

73 W[alt Whitman]., "Encampment of the Caravan," New-York Evening Post (April 21, 1851), 1, transcribed in Katz, "Previously Undocumented Art Criticism," 221-222.

74 See, for example, Arthur L. Ford, "The Rose-Gardens of the World: Near East Imagery in the Poetry of Walt Whitman," Walt Whitman Quarterly Review 5 (Summer 1987), 12-20.

75 Whitman, "Encampment of the Caravan." The New York Spectator reviewer of Rockland Lake from 1840 praised the artist for his skill in "catching and delineating the atmosphere; as also in the difficult work of adapting the atmosphere to the distances" ("Landscape Paintings"); another reviewer said of Talbot's 1844 landscape of New Hampshire's White Mountains that the "aerial perspective" was "very fine" (New York Daily Tribune, May 27, 1844), and another went into somewhat more detail: "He has caught the morning mist as it creeps up the mountains, and the moisture of the picture seems absolutely palpable. The trees look as if a breath of air would shake the dew drops from their leaves" (American Republican, May 20, 1844).

76 See Klein, “Art and Authority,” 1556. 
77 "An Hour at the Academy of Design."

78 Leaves of Grass (1855), 81.

79 The story is related by many Whitman scholars and biographers; see, for example, Justin Kaplan, Walt Whitman: A Life (Simon \& Schuster, 1980), 202-212.

80 "April Afternoon Ramble," "An Hour at the Academy of Design," and "Talbot's Pictures."

81 New York Mercantile Union Business Directory (New York: French and Pratt, 1850), 298; the advertisement for the school appears in the New York Post of April 211851 and reappears throughout the spring of that year.

82 Thomas Seir Cummings, Historic Annals of the National Academy of Design (New York: G. W. Childs, 1861), 238.

83 A notice of the sale of Belastier's collection mentions a "piece of tropical scenery, by JESSE TALBOT." The purchaser, who acquired it for \$55, was “Gov. Washington Smith," so called because he was the governor of the New York Almshouse; see Julie Miller, Abandoned: Foundlings in Nineteenth-Century New York City (New York: New York University Press, 2008), 118. Interestingly, the Almshouse was a plaintiff in the case against the Art-Union; see "The American Art-Union: Decision of the Supreme Court," New York Times (June 12, 1852). Also perhaps not coincidentally, the painting entered the Saco Museum's collection as a gift from The Wardwell, founded as a home for the elderly in 1889. Its provenance before that is unknown. Kim Boisvert (Executive Director, The Wardwell) to the author, December 1, 2015.

84 Both are in the collections of the New Haven Museum, Connecticut. I am grateful to Mary Christ (Collections Manager, New Haven Museum) for confirming their provenance in an email of February 10, 2016. The folk tale that inspired the paintings was also taken up by Henry Wadsworth Longfellow in his poem "The Phantom Ship," published in his 1858 volume Birds of Passage. Walt Whitman's close friend and early supporter John Townsend Trowbridge (1827-1916) was a descendant of the New Haven Trowbridges; see F. W. Chapman, The Trowbridge Family, or The Descendants of Thomas Trowbridge, One of the First Settlers of New Haven, Conn. (New Haven: Punderson, Crisand \& Co.), 287, 323-24. This suggests the possibility, as yet unexplored, that Whitman might have played a role in the Phantom Ship commission. I am grateful to Brandon James O'Neil for pointing out this connection. For more on Whitman and Townsend, see Stephen Rachman, "Trowbridge, John Townsend (1827-1916)" in LeMaster and Kummings, Walt Whitman: An Encyclopedia, available on the Walt Whitman Archive.

85 The originals are all unlocated; several small-scale versions of Indian's Last Gaze have appeared in public art sales, and the engraving of On the funiata can be seen in Bayard Taylor, "The Scenery of Pennsylvania," in The Home Book of the Picturesque: Or American Scenery, Art, and Literature (New York: G. P. Putnam, 1852), between pages 94 and 95. It is also reproduced in O. J. Victor, "Character in Scenery," Cosmopolitan Art Fournal 3 (September 1858), 209. For Discovery of the Hudson, see (for example) "Art," New York Observer and Chronicle, April 9, 1868; for Indian's Last Gaze, see "Our Artists and Their Whereabouts," Cosmopolitan Art fournal 2 (September 1858), 209; and for the biblical series, see "Talbot's Great Paintings," Brooklyn Daily Eagle, April 17, 1862. The biblical 
paintings were presented alongside a lecture by the Rev. Samuel Hanson Cox, "Chancellor of the Ingham University, Leroy, New York." The series seems to have been a long time in the making; beginning in 1854 there were frequent newspaper reports that it was in progress, but it does not seem to have been seen publicly until its 1862 showing in Brooklyn.

86 In 1855, Benjamin published a poem on a landscape painting by Talbot that he presumably owned. "On a Small Landscape," Ballou's Pictorial Drawing-Room Companion 9 (1855), 59.

87 Talbot's 1876 address is given as "Rondout, N. Y." in Maria Naylor, The National Academy of Design Exhibition Record, 1861-1900 (New York: Kennedy Galleries, 1973), 915. Further, Talbot's 1876 letters to A. J. Davis and T. Addison Richards (see note 9) were both sent from Rondout and both indicate that "Mrs. Burhans"/"my daughter Mary Augusta" (respectively) is living under the same roof. Burhans is known to have been a resident of Ulster County (Wynkoop, Schuremans, of New Fersey, 94-95). Richards was president of the National Academy at the time; Talbot's letter to him praises Mary Augusta's paintings and begs that they be considered for the Academy's annual exhibition.

88 Between 1857 and 1859, Talbot offered sixteen titles to the association's lottery. See Cosmopolitan Art Fournal 2 (December 1857); 3 (December 1858); and 4 (December 1859). With the exception of View on the Susquehanna, $40 \times 60$ inches (offered in 1857), all are small-scale works. On the Cosmopolitan Art Association and lottery laws, see Klein, "Art and Authority," 1559. For later works exhibited at the National Academy, see Naylor, Exhibition Record, 1861-1900, 915.

89 "Fatal Effects of a Fall."

90 "Jesse Talbot," findagrave.com/memorial/55213429/jesse-talbot. 